\title{
Products Liability: Trends and Implications
}

\author{
Roland N. McKean†*
}

The use or consumption of various products, from aircraft engines to lathes and hairsprays, often results in accidents and injuries, sometimes to the purchaser and sometimes to third parties. The problem of allocating these losses-a problem which lawyers label "products liability" - _has for many years been a subject of great concern. The losses referred to have usually resulted from injuries to persons or property, though in recent years the damages considered have sometimes included what has been termed "economic loss"-the loss suffered by a user because a product did not provide the expected services. ${ }^{2}$

In choosing among alternative products liability arrangements, one must consider the effects of these arrangements (1) on fairness or equity, and (2) on the behavior of various persons affected and hence on resource allocation. Suppose some innocent non-drinking by-

+ Professor of Economics, University of Virginia. I am indebted to the Joint AEA-AALS (American Economic Association and Association of American Law Schools) Committee and through the Committee to the Walter E. Meyer Research Institute for financing the study. For support of work that contributed to the study I am also indebted to the Center for Advanced Studies at the University of Virginia and to the Lilly Endowment grant to the University of California for the purpose of studying property rights. For background and suggestions I owe special thanks to Mr. Walter A. Reiser, Director of the Legal Method Program at Harvard Law School; Professors Robert Braucher, David F. Cavers, and Robert E. Keeton of the Harvard Law School; and Professor William Cohen of the UCLA Law School.

The AEA-AALS Committee arranged for a number of critics and discussants to comment on the study in March, 1969, at Stanford University. Since that time, the paper has been updated but not revised to reflect those criticisms.

A short modified analysis, Products Liability: Implications of Some Changing Property Rights, aimed primarily at economist readers, is being published by the Quarterly Journal of Economics.

Since the preparation of this study, an excellent volume pertaining to many of these issues has appeared: G. Calabresi, The Costs of Accidents: A Legal and Economic ANALYSIS (1970).

- Throughout this Symposium, this paper will be cited simply as McKean.

1 It might well be called "liability for damage or loss" or "user or producer liability," but it is economical now to use the term "products liability" because its meaning is so widely understood.

2 A separate though related topic has been the question of liability for damages inflicted on others by a firm's or individual's production or consumption process. 
stander loses an eye when a beer bottle explodes. To most persons it seems unfair to have the bystander bear the entire burden unaided, and they prefer institutional arrangements that yield some other outcome. Most thoughtful persons will also be concerned with the ways in which behavior and hence resource allocation are affected. If customers and bystanders could not inflict meaningful penalties, through bargaining, through reduced purchases of risky products, or through lawsuits-bottlers might be sorry about these accidents, but they would not find the accidents as disadvantageous as they would if they had to pay additional penalties. They would find it relatively inexpensive to put beer in low quality, hazardous containers, and such accidents would be relatively frequent (in comparison with a situation in which producers paid higher penalties). On the other hand, if competitive pressure or judicially imposed liability forced bottlers to bear part of the damages, such accidents would become comparatively expensive to the bottlers, and they would find it relatively rewarding to put beer in less hazardous containers. The degree of adaptation would depend on the severity of the penalty. To take an extreme illustration, if the penalties were sufficiently large, bottlers might find it economical to put beer in supersafe containers that cost $\$ 5$ each, even though it meant selling much less beer, reducing output, and releasing resources which would then be shifted to other uses. In short, (except in certain hypothetical circumstances) alternative arrangements will have different impacts on production processes, the purchase of insurance, the way particular resources are used, the allocation of resources, and the options open to consumers, as well as on fairness.

This study reviews (1) the literature on products liability and (2) the economic implications of products liability law to determine whether these implications are being discussed critically and carefully. Needless to say, it is hoped that the study will be useful in itself. More importantly, however, it is hoped that the study will stimulate economists to be concerned more frequently with real life legislation, court decisions, and institutional arrangements, and stimulate lawyers to be concerned more systematically with the economic implications of the legal framework generally. Along these lines, it seems important for both groups, when discussing policies, to appreciate the extent to which they are employing tested hypotheses about the consequences of alternative actions and the extent to which they are utilizing their individual judgments about untested propositions. This study of products liability should help emphasize the fact that there are a few, but only a few, tested hypotheses about behavior and 
that our judgments concerning the consequences of alternative arrangements can often legitimately differ. This fact, plus the fact that we must judge the values of those consequences, leads to understandable disagreement about policy. It is perhaps all the more important, therefore, to try to clarify the implications (and the uncertainties about the implications) of alternative institutions.

\section{Do We Have Criteria of Fairness and Optimal Resource Allocation?}

It might be stressed at the outset that this paper will not attempt to identify optimal policies but will simply trace out some of the consequences of products liability arrangements to determine whether commentators recognize the implications of different arrangements. Indeed, as far as optimality is concerned, while each individual can identify the policies he prefers, there is no criterion of preferredness that all members of a group are compelled by logic to accept.

Consider fairness. What is fair or equitable? We cannot ascend some mountain and find a tablet revealing an answer that is necessarily correct for all persons. It is not that values are relative; you might believe that your values are correct for everyone, and I might insist that mine are correct, but the two sets of values would not necessarily coincide, and there would be no way for me to demonstrate that mine are right. In the example cited above, most persons would agree that for the innocent bystander to bear the costs would be unfair. (Some persons might disagree even with that proposition if, for example, the bystander was very wealthy and the others involved were poor widows and orphans.) To most persons it would also seem unfair for the buyer to shoulder the financial burden due to the exploding bottle. But at least some persons might regard it as inequitable for any group we could name, for example, taxpayers in general, to bear the financial burden.

Moreover, to choose the optimal policy, the trade-offs between fairness (that is, whatever redistributions of wealth one likes) and improved resource allocation or "total output" would have to be specified. ${ }^{3}$ But there are no "correct" rates at which the nation should trade fairness for economic efficiency, and there is little likelihood that people could agree regarding such rates. Thus, for this reason too, one can hardly say that a particular policy is preferred from the standpoint of society.

I If transaction costs compelled us to trade efficiency in order to achieve greater equity. For the non-economist these concepts will be explained later. 
Furthermore, there is no ultimately correct criterion of optimal resource allocation. Consider a little nation of three people. Is it right to allocate resources so as to maximize the combination of goods specified by individual A? Is it correct to allocate resources in accordance with the wishes of the majority? Should resources be used so that each person is as well off as he can be, as he sees his well-being, without making someone else worse off, as he sees his wellbeing? (Voluntary exchanges tend to work toward this last situation.) None of these goals is inherently correct. Logic does not forbid one to prefer something else.

\section{Developments Concerning Products Liability 4}

Liability for damages inflicted on others has a long history. Even in early eras the ill will of part of the community and the threat of retaliation must have imposed penalties on persons who damaged others. By the Middle Ages, fairly strict liability for injuries-without direct contract, misrepresentation, or evidence of negligencewas often the rule. ${ }^{5}$ Later, as industrial societies developed, greater freedom of action was stressed, and liability was imposed only if "due care" was not exercised and then only in a restricted range of circumstances.

- One of the most important conditions for liability for a defective product was the existence of privity, or a direct contractual relationship. A manufacturer might be liable to the wholesaler, the wholesaler to the retailer, and the retailer to his customer, but the manufacturer was not liable to remote customers, and nobody was liable to third parties because there was no contractual relationship with them. In general, though there were exceptions, the requirement of privity was upheld in England and the United States throughout the 19th century. In one famous case, Winterbottom $v$. Wright, ${ }^{8}$ in which a coach with a defective wheel had overturned,

4 Only the high spots will be reviewed here. For more detail see such articles as Leavell, The Return of Caveat Venditor as the Law of Products Liability, 23 ARK. L. Rev. 355 (1969), or Kessler, Products Liability, 76 YALE L.J. 887 (1967). An especially comprehensive survey is in Noel, Manufacturers of Products-the Drift Toward Strict Liability, 24 TENN. L. REv. 963 (1957). A very readable summary, written by an eminent authority on the subject, is Prosser, The Assault Upon the Citadel (Strict Liability to the Consumer), 69 YALE L.J. 1099 (1960). See also Green, Should the Manufacturer of General Products Be Liable Wilhout Negligence? 24 TENN. L. REv. 928 .(1957).

W. Hamilton's famous article, The Ancient Maxim Caveat Emptor, 40 YALE L.J. 1133 (1931), gives a fascinating history of the difficulties confronting the buyer from the Middle Ages until recent times. Most of the cases pertain to outright fraud, however, and have little bearing on products liability issues today.

5 See generally Green, supra note 4, at 930-32.

( 152 Eng. Rep. 402 (Ex. 1842). 
Lord Abinger said: "There is no privity of contract between these parties; and if the plaintiff can sue, every passenger, or even any person passing along the road, who was injured by the upsetting of the coach, might bring a similar action. Unless we confine the operation of such contracts as this to the parties who entered into them, the most absurd and outrageous consequences, to which $I$ can see no limit, would ensue."7

Even with the privity requirement, most persons suffering injury or loss could do several things to help themselves. First, where privity existed, the buyer could seek compensation from the seller. (And, where one person's action directly injured another, the injured party could also seek a court judgment, though such cases take us away from the category of products liability.) Second, the injured party could sue for fraud. The requirements for recovery on this basis were rather stringent, however: the seller must have knowingly ${ }^{8}$ and intentionally ${ }^{8}$ committed the fraud, the buyer must have justifiably 8 relied on the representation, and damage resulting from the fraud must have occurred. ${ }^{8}$ Still, liability for fraud did not depend on privity, was not thwarted by disclaimers, could encompass economic loss and punitive damages, ${ }^{10}$ and was (as it still is) an important part of the law pertaining to liability.

Third, the existence of even moderate competition gives the customer some protection.11 Most firms must worry about attracting customers from other businesses and about preventing customers from turning to rival firms. In deciding how safe to make their products, what kind of warnings and disclaimers to issue, what to do in case customers suffer injuries, and how generous to be in replacing defective items, managements will weigh the costs of proceeding in any of

$7 I d$. at 405. Another member of the court added, "This is one of those unfortunate cases in which there certainly has been a damnum, but it is a damnum absque injuria; it is, no doubt, a hardship upon the plaintiff to be without a remedy, but by that consideration we ought not to be influenced. Hard cases, it has been frequently observed, are apt to introduce bad law."

Most persons find Lord Abinger's words amusing nowadays, but he was probably worried (though he had his own mind made up) about the basic issues that are still with us: would the abandonment of privity, or other steps toward strict liability of producers, bring more cost than gain?

8 Economists might note the imprecision of these requirements and of the provisions and definitions cited subsequently. A great deal is left to the discretion of the courts. This may seem highly undesirable, but a little reflection suggests that spelling out provisions unambiguously would usually be uneconomical, that is, would cost more than it would gain (as most of us would assess the costs and gains).

- Sebert, Products Liability-the Expansion of Fraud, Negligence, and Strict Tort Liability, 64 MICH. L. REv. 1350, 1351 (1966).

10 Id. at 1354.

11 See the thoughtful article by Plant, Strict Liability of Manufacturers for Injuries Caused by Defects in Products-An Opposing Diew, 24 TzNn. L. REv. 938 (1957). 
these directions against the gains from doing so. Even if monopoly power exists, but particularly if there is at least moderate competition, producers will find it relatively expensive to neglect all safety features, to issue little information about their products, to ignore injuries resulting from the use of their products, and to allow few returns of defective or undesired items. They will find it expensive in terms of the impact on future sales and thence on profits, even if court judgments rarely help the buyer. ${ }^{12}$ Indeed, with respect to minor consumer losses and complaints, one must rely mainly on competition to constrain producers, because it is too costly to go to court over books with such small print that they cause headaches or shirts that are damaged by the laundry.

\section{A. Evolution of Sales Law}

The above safeguards (the forces of competition, liability for fraud, and products liability where privity exists) were long ago deemed insufficient in connection with certain products and activities. There is a lengthy history of special concern about foods and about "inherently or imminently dangerous" or "ultrahazardous" products (e.g., explosives). Only "a decade after Winterbottom $v$. Wright, the New York Court of Appeals in Thomas $v$. Winchester ${ }^{13}$ held a manufacturer liable to a consumer where a bottle of belladonna had been mislabelled 'dandelion,' and caused injury to the plaintiff. Lack of privity, said the court, is no defense."14 In fact, quite a few exceptions to the privity rule developed late in the 19th and early in the 20th centuries. ${ }^{15}$

In developing special rules for these categories of products, the courts were probably groping, unconsciously, for changes in the assignment of rights that would yield more gain than cost. ${ }^{16}$ Where injuries resulted from the use of foods, products involving intimate bodily use, or "ultrahazardous" products, one might have argued that either private contracting or liability with fault plus the privity requirement yielded inequities and inefficiencies because of heavy information costs that might be reduced. Interest in liability for injuries from these products rose as events made the effects more important or

12 This is not to say, of course, that competition will move manufacturers to turn out completely safe products, dry cleaners never to lose buttons, or producers to compensate customers for all damages or disappointments. Also, if competition is extremely weak, its effects will be weak. Your phone company, public school, or tax assessor will not be greatly worried for fear you might turn to a competitor.

136 N.Y. 397 (1852).

14 Jaeger, Privity of Warranty: Has the Tocsin Sounded? 1 DuQuesNE U.L. REv. 1, 49, 50 (1963).

15 Feezer, Tort Liability of Manufacturers, 10 MnN. L. REv. I (1925).

16 Coase, The Problem of Social Cost, 3 J. LAw \& Econ. 1, 19-27 (1960). 
caused people to regard the effects as being more important than before. For example, concern about foods soared after the publication of Upton Sinclair's books. ${ }^{17}$

Such categories of products were highly imperfect for the purpose of assigning liabilities, yet their use may have seemed preferable to always requiring privity. Ambiguities abound, for instance, in the label "dangerous product." If it is misused, a paring knife can be dangerous; if information is sufficiently poor, foods can be dangerous; if quality control is poor enough, many metal (and other) products can be hazardous; some drugs and cosmetics are ultrahazardous for some persons though not for most. If the hazard is well known or obvious, there may be no hazard as far as courts' assignment of liabilities is concerned. (A few years ago cigarette manufacturers might have been held liable for lung cancers attributed to smoking; now there is more inclination to regard the risk as an obvious one that the smoker knowingly accepts.) As these categories developed, these ambiguities allowed the courts leeway in weighing the harmful effects of judgments against the good effects, and the results were probably better than the results of firm, clear-cut rules would have been. ${ }^{18}$ To repeat, the courts were apparently probing for improved rules, even though the arguments were imprecise and the new arrangements inevitably far from perfect.

The major breakthrough, however, came in 1916 in the famous case of the collapsing automobile, MacPherson v. Buick Motor Co.19 The New York Court of Appeals held that the manufacturer was liable, in the absence of privity, for injuries resulting from the use of a product, whether or not inherently dangerous, if there was evidence of "negligence" in the manufacture or assembly of the product. Judge Cardozo, writing for the court, apparently expressed a view that many persons had come to hold and that was soon to have enormous influence: "We have put aside the notion that the duty to safeguard life and limb, when the consequence of negligence may be foreseen, grows out of contract and nothing else."20

17 Prosser notes that Upton Sinclair "said later that he had aimed at the public's heart, and by accident hit it in the stomach." Regier, The Struggle for Federal Food and Drug Legislation, 1 LAW \& Conremr. ProB. 3, 9 (1933), cited by Prosser, supra note 4, at 1106.

18 As Coase notes, such phrases as "Users must handle products with reasonable care" suggest that judges were seeking to weigh harm against utility. Coase, supra note 16, at 22.

19217 N.Y. 382, 111 N.E. 1050 (1916).

20 While the general thrust of this view is clear, note that it too is far from unambiguous. Do producers have a duty to turn out only completely safe products? Pursuing 
After MacPherson, this position was adopted in case after case, and eventually in all states (with the possible exception of Mississippi). The ruling was applied not just to special categories, such as food, firearms, and explosives, but to such varied products as a sanitary napkin, ${ }^{21}$ an inflammable celluloid comb, ${ }^{22}$ and a defective bar stool. ${ }^{23}$ MacPherson led to a number of widely accepted, but not universal, rules. Those who may be liable include producers of component parts, assemblers, lessors who rent products to their customers, firms that repair or recondition, and firms that label a product their own even though some other firm actually manufactures the item. The product must usually have posed significant danger to life and limb (though even under the MacPherson doctrine, awards for property losses were occasionally made), and courts have generally refused to make awards for injuries arising from minor hazards, such as a defective high heel or a coffee-can key. ${ }^{24}$ Nonetheless, as a result of MacPherson, there was unquestionably a major shift toward producer liability in a broader range of circumstances.

Other extensions of such liability were brought about through ad hoc devices. It is often difficult to prove negligence on the part of a manufacturer, but in some instances the courts chose to take negligence for granted, applying the doctrine of "res ipsa loquitur": let the matter speak for itself. If a bottle of soft drink is found to contain a cockroach, it seems quite unlikely that anyone, "after the bottling was completed, opened the container and inserted the insect. The courts assumed that the production process involved negligence. ${ }^{25}$ Similarly, if a sealed unit in a refrigerator or machine caused damage, it was not always necessary to prove that there was negligence; the courts often concluded that the matter spoke for itself. ${ }^{26}$

Another way of getting around the privity requirement was to regard the wife who buys an item as an agent for her husband so that, even though he has no direct contractual relationship with the seller, the latter may be liable if the husband is injured while using the product. $^{27}$ It was also decided that liability extended to third party

such a goal would eventually bring costs in excess of gains in almost everyone's eyes, and achieving the goal is simply impossible.

21 La Frumento v. Kotex Co., 131 Misc. 314, 226 N.X.S. 750 (New York City Ct. 1928). 22 Farley v. Edward E. Tower Co., 271 Mass. 230, 171 N.E. 639 (1930).

23 Okker v. Chrome Furniture Mfg. Corp., 26 N.J. Super. 295, 97 A.2d 699 (1953).

24 Timpson v. Marshall, Meadows \& Stewart, Inc., 198 Misc. 1034, 101 N.Y.S.2d 583 (Sup. Ct. 1950); Boyd v. American Can Co., 249 App. Div. 644, 291 N.Y.S. 205 (1936). For a discussion and other citations, see Noel, supra note 4, at 969 .

25 See, e.g., Escola v. Coca-Cola Bottling Co., 24 Cal. 2d 453, 150 P.2d 436 (1944).

26 Ryan v. Zweck-Wollenberg Co., 266 Wis. 630, 64 N.W.2d 226 (1954).

27 Haut v. Kleene, 320 III. App. 273, 50 N.E.2d 855 (1943). In this case, it was the wife 
beneficiaries, including guests in the home, ${ }^{28}$ but not bystanders. ${ }^{29}$ Other extensions of liability to instances where there was no direct contract resulted from the master-servant rule (respondeat superior), under which it was held that the master must answer for injuries caused by the servant. ${ }^{30}$

These devices are often criticized as being tortured or "artificial" attempts to introduce strict producer liability. It is true that, if there were perfect knowledge, such categories or lines of demarcation would be absurd, but under conditions of uncertainty one might without being illogical judge these rules to be better than the alternatives. The courts were (properly, it seems to me) uneasy about proceeding to strict liability lest it result in more harm than good, yet they felt that these small steps would yield more good than harm. (Similarly one might be uneasy about permitting automobiles to proceed in the face of a red traffic light if drivers deem it safe, yet feel confident that allowing right turns on a red light would yield more good than harm.)

Another development that reflects the shift toward caveat venditor has been the expanded possibility of recovering on grounds of fraud. As noted earlier, recovery for fraud has several prerequisites; but in recent years, the courts have been making it somewhat easier for the plaintiff to win, particularly by having less stringent requirements concerning the knowledge of falsity by the defendant and reliance by the plaintiff on the producer's representations. ${ }^{31}$ Since recovery on grounds of fraud is not barred by disclaimers, does not require any suggestion of warranty, and may yield punitive damages, these developments may be fairly important. In any event, they also widen the range of circumstances in which the producer may be liable.

An important development has been the increase in producers' liability based on express and, particularly, implied warranty. (This change could be regarded as part of the evolution of strict liability under tort law rather than the evolution of sales law, but at least many of these

who suffered injury, in fact death, due to preparing food (rabbits) that had been purchased by the husband.

28 Dipangrazio v. Salamonsen, 64 Wash. 2d 720, 393 P.2d 936 (1964); Welch v. Schiebelhuth, 11 Misc. 2d 312, 169 N.Y.S.2d 309 (Sup. Ct. 1957). These cases involved, respectively, a child guest who fell through a plate glass window, and relatives who were guests and ate a cake that contained toxic elements.

20 See, e.g., Rodriguez v. Shell's City, Inc., 141 So. $2 d 590$ (Fla. Dist. Ct. App. 1962), involving a bystander who was hit in the eye by a piece of a rubber disk that disintegrated.

30 For instance, a firm is usually liable if an employee uses a machine, while on duty, so as to injure someone. Southern Paramont Pictures Co. v. Gaulding, 24 Ga. App. 478, 101 S.E. 311 (1919).

81 Comment, Products Liability-The Expansion of Fraud, Negligence, and Strict Tort Liability, 64 MrCH. L. REv. 1350, 1351-52 (1966). 
changes occurred before the famous Henningsen ${ }^{32}$ case, to be discussed in the next section.) Perhaps the best way to indicate the main thrust of this development is to compare some of the provisions of the Uniform Commercial Code (UCC) with the provisions that were generally accepted previously. The UCC is a compilation of sales and commercial law which was designed for adoption by each state, so that uniform provisions among the states would emerge. ${ }^{33}$ Under the Code (as adopted, for example, by Kentucky) express warranty is now deemed to arise, not merely out of affirmations about a product upon which the buyer relies and which induce the purchaser to buy the product, but also out of the use of description or samples or models. ${ }^{34}$ There need be no specific intention to warrant. All goods sold must now be like the sample; it is no longer enough that the "bulk" of such goods be "in reasonable conformity" with the sample.

It is implied warranty, however, that has been extended in highly significant ways. An implied warranty of "merchantability" now grows out of every sale where the seller is a "merchant," including the sale of food to be consumed on the premises (formerly excluded). Needless to say, these phrases are ambiguous. Thus, some persons interpret merchantable to mean free of defect, which simply substitutes for "defect" another term to be defined; and the UCG defines merchantable to mean that the goods must pass without objection in the trade, have fair average quality fit for ordinary purposes for which the goods are used, be adequately packaged, and fulfill the promises on the container. ${ }^{35}$ Also, as some decisions moved in the direction of strict liability in tort, implied warranty was in effect expanded greatly. ${ }^{36}$ Despite ambiguities and disagreement, these developments increase the probability that a manufacturer or other seller will be liable when losses 'occur.

The UCG also recognizes an implied warranty of fitness for a particular purpose as distinct from the item's ordinary purpose. ${ }^{37}$ For this warranty to hold, the seller must have reason to know the particular purpose, but it is not necessary for the buyer to have informed the

32 Henningsen v. Bloomfield Motors, Inc., 32 N.J. 358, 161 A.2d 69 (1960).

33 All states except Louisiana have now accepted the UnIForm Commercial Code.

84 Note, The Uniform Commercial Code and Greater Consumer Protection under Warranty Law, $49 \mathrm{KY}$. L.J. 240, 242-43 (1960).

35 Id. at 244, citing UNIFORM COMMERCIAL CODE § 2-314(1).

36 Recent developments are not completely consistent, with the rules of contract being modified on the one hand, but with liability in tort also being mentioned, which would make the rules of contract largely irrelevant. Again see Prosser, The Fall of the Citadel (Strict Liability to the Consumer), 50 MiNn. L. REv. 791, $831-40$ (1966).

87 UNIFORM COMMERCIAL CODE \& 2-315. 
seller; the buyer must be relying on the seller's judgment in selecting or furnishing the goods (formerly the seller was liable only if he selected the goods); and purchase by trade name no longer implies that the buyer is relying on his own judgment rather than the seller's. The course of dealing and trade usage may generate implied warranties; for example, the court may decide that trade usage provides the seller with "reason to know" the particular purpose to which goods are put in a particular locality. ${ }^{38}$

The Code refrains from taking a stand on the privity issue, but it does try to reduce the cost of successive lawsuits by preventing a manufacturer from challenging the fact determinations of an earlier suitif the manufacturer refused to appear in the earlier suit. ${ }^{39}$ Disclaimers, while still playing important roles in sales relationships, have become less effective in preventing producer liability. ${ }^{40}$ Under the UCC the disclaimer rules are codified.41 Disclaimers must be "reasonable" and cannot negate express warranties (though an "entirety" clause stating that the contract contains all the agreed-upon terms may, nullify warranties made orally). A major aim is to prevent the use of disclaimers that are likely to be overlooked by purchasers. If fitness for a particular purpose is denied, it must be in "conspicuous writing." Implied warranty can be nullified by the purchaser's refusal to inspect or by his failure to detect defects that his inspection "should" have detected.42 Also, a seller can still sell an item "as is," eliminating all implied warranties, if he makes this clear.

Advertising directly to consumers can create warranties to them. In Baxter v. Ford Motor Co., ${ }^{43}$ the manufacturer was held to be liable because a windshield advertised as shatterproof did in fact shatter when - struck by a stone. At the same time a certain amount of "puffing" in advertisements or sales talks is regarded as permissible. A normal buyer is apparently assumed to discount the seller's views to allow for some tacitly understood or expected degree of optimism about the product.

38 Note, supra note 34 , at 249.

80 UnIrorm Commercial CODE \& 2-607.

10 As strict liability under tort (see Part B infra) became accepted in cases where personal injuries were involved, disclaimers seemed to be irrelevant, since contract law was irrelevant in such instances. But in fact, disclaimers are still pertinent to the outcomes of such lawsuits.

11 UNIFORM COMmerctar CODE § 2-316.

12 A seller of lumber was held not liable for injuries resulting from a board breaking since the customer had had plenty of opportunity to inspect and test the lumber and avoid the danger, Collum v. Pope \& Talbot, 135 Cal. App. 2d 784, 288 P.2d 75 (1955), cited in Green, supra note 4, at 936 .

13168 Wash. 456, 12 P.2d 409 (1932). 


\section{B. Recent Shifts toward Strict Liability under Tort}

Strict liability under tort can be defined loosely as liability because a wrong was done or a "duty" neglected, not because a contract was unfulfilled. No imputation of negligence is necessary (though a "defect," which may to some extent simply substitute another word for negligence, is necessary), and no contract need be implicated. To many observers it appears that products liability has been evolving rapidly in recent years toward strict liability under tort. The following are typical comments: "With privity on the wane, caveat venditor will be the rule, not caveat emptor; the time has come to hold a requiem for this ... anachronism." 44 "It seems safe to predict that strict liability for products will soon be the established law in this country." 45

But even strict liability does not mean liability for injury or economic loss regardless of circumstances. There must be reason to believe the product was "defective." The user must employ the product in a reasonable manner (a hammer manufacturer will not be held liable simply because a user of the hammer manages to hit himself in the head with it). And there are many other issues that are left openmany circumstances in which producers would still not be liable. Before considering these issues, however, let us review the recent steps that have led toward strict liability.

"In the field of products liability, the date of the fall of the citadel of privity can be fixed with some certainty. It was May 9, 1960, when the Supreme Court of New Jersey announced the decision in Henningsen v. Bloomfield Motors, Inc."40,47 Mr. Henningsen had purchased a car manufactured by Chrysler Corporation from Bloomfield Motors, a dealer. Mrs. Henningsen suffered injuries when the car suddenly veered to the right and ran into a wall, presumably due to a defective steering gear. Without any evidence of negligence on the part of the manufacturer, the court held Chrysler as well as the dealer liable, explaining: "An implied warranty that it (the product) is reasonably suitable for use as such accompanies it into the hands of the ultimate purchaser. Absence of agency ... is immaterial."4s The court also said, "We see no rational doctrinal basis for differentiating between a fly in a bottle of beverage and a defective automobile." 40 There had been earlier and unsuccessful attempts to put automobiles in the cat-

44 Jaeger, supra note 14, at 142.

45 Wade, Strict Tort Liability of Manufacturers, 19 Sw. L.J. 5, 5 (1965).

4632 N.J. 358, 161 A.2d 69 (1960).

47 Prosser, supra note 36 , at 791.

4832 N.J. at 384,161 A.2d at 84.

19 Id. at 383, 161 A.2d at 83. 
egory of "deadly and dangerous instrumentalities" or to apply the rules for "ferocious animals" to the "devil wagon," 50 but Henningsen appeared to eliminate the requirements for privity and negligence with respect to all products and to put the effectiveness of disclaimers in doubt. Within a few years the Henningsen precedent was followed in state after state in case after case pertaining to a wide variety of products, including a glass door, shotgun, abrasive disc, electric cable, pleasure boat, dental chair, and hula skirt. ${ }^{51}$

Among the important subsequent cases was Goldberg v. Kollsman Instrument Corp. ${ }^{52}$ which seemed to discard all previous guidelines in order to seek a "just" compromise among conflicting interests. ${ }^{53}$ This supported the trend toward strict liability, for the decision did not hinge on privity or negligence, and indeed the decision described the situation as one of "strict tort liability." In this case Lockheed had purchased altimeters from Kollsman and installed them in the aircraft it manufactured. One of the planes, flown by American Airlines, crashed. A defective altimeter was allegedly the cause of the accident. The estate of a deceased passenger brought an action against the carrier, the parts manufacturer, and Lockheed. The case raised complicated issues of choice of law, privity, and warranty, but for this paper the significant thing was that the New York Court of Appeals rested its decision on the law of tort. A special feature of Kollsman was that, in the end, the court freed the parts manufacturer from liability, not because privity or negligence was lacking but because he felt that the airplane manufacturer's liability provided sufficient protection to the passengers!

A more important landmark was Greenman v. Yuba Power Products, Inc., ${ }^{54}$ in which the purchaser of a power tool, a combination sawdrill-lathe, sued the manufacturer. There was nothing wrong that would ordinarily be called a defect, but the design of the tool was such that it was able to hurl a piece of wood through the air, hitting and injuring the user. In this decision Justice Traynor explicitly stated that ". . . the liability is not one governed by the law of contract warranties but by the law of strict liability in tort." $" 55$ Hence it made no

80 Lewis v. Amorous, 3 Ga. App. 50, 55, 59 S.E. 338, 340 (1907), cited in Ehrenzweig, Negligence Without Fault, 54 CAIIF. L. REv. 1422, 1435 (1966) (originally published in 1951).

51 For details see Prosser, supra note 36, at 794-98.

6212 N.Y.2d 432, 191 N.E.2d 81, 240 N.Y.S.2d 592 (1963).

83 Cowan, Some Policy Bases of Products Liability, 17 Stan. L. REv. 1077, 1081 (1965).

5459 Cal. 2d 57, 377 P.2d 897, 27 Cal. Rptr. 697 (1963).

55 Id. at 63, 377 P.2d at 901, 27 Cal. Rptr. at 701, quoted in Prosser, The Fall of the Citadel, supra note 36, at 804 . At this point Prosser also cites numerous subsequent cases in which the courts agreed with Traynor's view. 
difference whether there was privity or negligence on the part of the manufacturer, or whether the purchaser had provided notice of breach of warranty in the proper way. And the decision seemingly broadened further the possible interpretations of the word "defect."

A New Jersey court decided that, in view of Greenman v. Yuba Power Products, strict liability in tort applied to "economic loss" as well as to personal injuries. In Santor v. A. \& M. Karagheusian, Inc., ${ }^{56}$ a man bought a rug for his business establishment and allegedly suffered losses of sales and profits when the rug rapidly changed to an unattractive color. The rug was judged to be unmerchantable or defective, and the purchaser collected from the manufacturer without the existence of privity, a showing of negligence, the occurrence of any personal injuries, or resort to sales law. Seely $v$. White Motor Co.g7 however, "pulled the rug out from under the Santor decision" according to one pun-loving writer. ${ }^{58}$ The plaintiff bought a truck for his business operation. The truck seemed to have something wrong with its weight distribution, at least for the purpose for which it was bought, and it "galloped," caused persistent difficulties, and eventually overturned. While partial damages were awarded, the court went out of its way to say that absolute liability in tort should not apply to pocketbook losses:

We are of the opinion ... that it was inappropriate to impose liability on that basis in the Santor case, for it would result in imposing liability without regard to what representations of quality the manufacturer made. ... Had the manufacturer not so described the rug, but sold it "as is," or sold it disclaiming any guarantee of quality, there would have been no basis for recovery in that case. Only if someone had been injured because the rug was unsafe for use would there have been any basis for imposing strict liability in tort.

The distinction that the law has drawn between tort recovery for physical injuries and warranty recovery for economic loss is not arbitrary ... [but] rests ... on an understanding of the nature of the responsibility a manufacturer must undertake in distributing his products. ${ }^{59}$

The idea of strict liability for injuries to person or property is becoming more widely accepted. The extent of its acceptance is indicated

5644 N.J. 52, 207 A.2d 305 (1965).

5763 Cal. 2d 9, 403 P.2d 145, 45 Cal. Rptr. 17 (1965).

58 Comment, Manufacturer's Responsibility for Defective Products: Continuing Controversy over the Law to be Applied, 54 CALIF. L. REv. 1681, 1689 (1966).

$6963 \mathrm{Cal} .2 \mathrm{~d}$ at 17-18, 403 P.2d at 151, 45 Cal. Rptr. at 23. 
in Second Restatement of Torts in section 402A and the accompanying comment:

$\S$ 402A. Special Liability of Seller ${ }^{60}$ of Product for Physical Harm to User or Consumer

(I) One who sells any product in a defective condition unreasonably dangerous to the user or consumer or to his property is subject to liability for physical harm thereby caused to the ultimate user or consumer, or to his property, if

(a) the seller is engaged in the business of selling such a product, and

(b) it is expected to and does reach the user or consumer without substantial change in the condition in which it is sold.

(2) The rule stated in Subsection (1) applies although

(a) the seller has exercised all possible care in the preparation and sale of his product, and

(b) the user or consumer has not bought the product from or entered into any contractual relation with the seller.

The rule stated in this Section does not require any reliance on the part of the consumer upon the reputation, skill, or judgment of the seller who is to be held liable, nor any representation or undertaking on the part of that seller. The seller is strictly liable although, as is frequently the case, the consumer does not even know who he is at the time of consumption. The rule stated in this Section is not governed by the provisions of the Uniform Sales Act, or those of the Uniform Commercial Code, as to warranties; and it is not affected by limitations on the scope and content of warranties, or by limitation to "buyer" and "seller" in those statutes. Nor is the consumer required to give notice to the seller of his injury within a reasonable time after it occurs, as is provided by the Uniform Act. The consumer's cause of action does not depend upon the validity of his contract with the person from whom he acquires the product, and it is not affected by any disclaimer or other agreement, whether it be between the seller and his immediate buyer, or attached to and accompanying the product into the consumer's hands. In short, "warranty" must be given a new and different meaning if it is used in connection with this Section. It is much simpler to regard the liability here stated as merely one of strict liability in tort. ${ }^{61}$

60 In this section the word "Seller" includes "Manufacturer." RESTATEMENT (SECOND) OF TORTS \& 402A, comment $f$ (1965).

61 Id., comment $m$ at $355-56$. Other comments, e.g., at 348 and 349 , also emphasize that the meaning of $\$ 402 \mathrm{~A}$ is strict liability. 
Another aspect of the trend is that the definition of a "defect" continues to expand. The manufacturer may find himself liable for failure to build in certain safety features, even if this is quite difficult to do and even if the peril is obvious to the injured person. In Pike v. Frank G. Hough $\mathrm{Co.}^{62}$ an earthmoving machine called a paydozer backed up and killed a workman. Because of a huge rear engine box, the driver could not have seen a man six feet in height as far as 48 feet behind the paydozer. The manufacturer was held liable for neglecting his "duty" to reduce this hazard-even though rear-view mirrors projecting four feet from the sides of the cab would not completely eliminate the blind area, and even though the hazard may have been obvious to the workman. ${ }^{63}$

Also, the burden of proof concerning defects may be shifting somewhat. ${ }^{64}$ Instead of requiring the plaintiff to prove that a defect existed, the defendant may sometimes be obliged to prove that a defect did not exist. In one recent case, the plaintiff merely had to demonstrate that a steel piler's mechanical fingers dropped its load so as to result in the injury ${ }^{65}$ Other parts of the production line, for example, the air compression system, may have contained defects that caused the accident, but the manufacturer of the piler was held liable. The necessity of proving that his piler was not the defective component was in effect placed on the manufacturer.

In the past few years, products liability law has also been extended to another major product, namely, housing produced by large-scale builders. ${ }^{66}$ As one writer suggests, it was paradoxical a few years ago that so much protection was given to the buyer of a two dollar fountain pen in comparison with the protection given to the man who put all his savings into a house. ${ }^{67}$ Again, in this comparatively new application, both implied warranty and strict liability under tort are involved.68

622 Cal. 3d 465, 467 P.2d 229, 85 Cal. Rptr. 629 (1970).

63 The lower court granted a "nonsuit," thus favoring the defendant, but the Supreme Court of California decided that the plaintifs' evidence warranted a jury trial-that the evidence was "sufficient to support a jury verdict in their (the plaintiffs') favor." Id. at 637.

6421 StAN. L. REv. 1777, 1786 (1969).

65 Greco v. Bucciconi Eng'r Co., 283 F. Supp. 978 (W.D. Pa. 1967), aff'd, 407 F.2d 87 (3d Cir. 1969).

66 Comment, Extension of Strict Liability to the Construction and Sale of Buildings in Oregon, 48 ORE. L. REv. 411 (1969); Roberts, The Case of the Unwary Home Buyer: The

Housing Merchant Did It, 52 CORNELI L.Q. 835 (1967).

67 Id. at 835-36.

68 Schipper v. Levitt \& Sons, 44 N.J. 70, 207 A.2d 314 (1965); Kriegler v. Eichler Hames, Inc., 269 Cal. App. 2d 224, $74 \mathrm{Cal}$. Rptr. 749 (1969). In the latter case, the court found "no meaningful distinctions between ... mass production and sale of homes and the 
Along with the trend toward strict liability, there has been some tendency to increase the size of the awards in cases of severe injuries or multiple victims, reinforcing the effect of stricter liability. For instance, awards in automobile accident litigation seem to have risen. The dramatic examples, however, are the punitive damages awarded in some of the drug cases. ${ }^{69}$ Such damages are intended to punish, to encourage the injured to sue by making it more rewarding, and through these various effects to heighten the deterrence of potential offenders. ${ }^{70}$ Note also that insurance coverage may be disallowed on the grounds that it would defeat the aim of punishing particular offenders. ${ }^{71}$ These too are relevant developments, because with them, strict liability makes the neglect of safety features entail greater expected costs to producers than would otherwise be the case.

A factor that may work in the opposite direction is the expanded reliance on liability insurance. Some people believe that this phenomenon almost completely eliminates any tendency of the fault system to deter producer negligence, since the insurance company pays the bill. ${ }^{2}$ If so, expanded and perhaps modified insurance coverage may also dilute the impacts of strict liability. The actual effects of liability insurance depend partly on how sensitive premium charges, coverage, and chances of cancellation are to the individual firm's (or,

mass production and sale of automobiles ... ." 269 Cal. App. 2d at 227, 74 Cal. Rptr. at 752. There may be a distinction, however: it may be much more costly to apply products liability law to the production of homes, which may be why the application has been slow to appear.

68 The MER/29 cases bring out the potential significance of punitive damages. For instance, see Toole v. Richardson-Merrell, Inc., 251 Cal. App. 2d 689, 60 Cal. Rptr. 398 (1967). The defendants, several pharmaceutical firms, produced and distributed a drug (MER/29) which seemed to be an effective treatment for arteriosclerosis, one of the world's greatest killers. Unfortunately, the drug apparently turned out also to cause cataracts of the eye. Court actions are still going on, but punitive awards as of 1967 were said to total between $1 / 2$ and $3 / 4$ of a billion dollars! There are many important and unresolved issues, involving such matters as the amount of testing and experimentation that one prefers to have before the marketing of new drugs, the type of information and disclaimers that producers should issue, and the role that the Federal Drug Admin. istration should play. But for present purposes the central point is that awards are sometimes very high.

For a discussion of the special issues involved in the development and marketing of drugs, see Rheingold, Products Liability-the Ethical Drug Manufacturer's Liability, 18 Rutcers L. Rev. 947 (1964).

70 For information about these matters I am especially indebted to Barry G. West, Some Contemporary Corporate Problems Concerning Punitive Damages (unpublished paper submitted in satisfaction of the written requirements of the seminar on Legal Protection Against Hazardous Products and the Master of Law Degree, Harvard Law School, March 15, 1967).

71 Northwestern Nat'l Cas. Co. v. McNulty, 307 F.2d 432 (1962).

72 Fhrenzweig, supra note 50, at 1440-41. 
to a lesser extent, the industry's) record concerning damages and lawsuits. If premiums, etc., are sensitive to bad records, then firms will anticipate extra costs when they produce relatively risky products. If not, or if the sensitivity occurs only at a few major threshold points, there will be "ranges of product hazard" over which the threat of lawsuits may not affect the firm's costs. (This is not to say that the firm will have no concern about safety. It must still sell the product, and an enterprise cannot survive if it tries to market rubber skillets or bottles of beer that explode half the time.)

We cannot here determine just how sensitive the premiums and cancellations are to a firm's lawsuits or just how much the gaps in coverage affect each firm's decisions. Clearly there is some standardization and insensitivity in insurance provisions, partly because many states require some degree of uniformity, and partly because some degree is simply economical. ${ }^{73}$ Partly due to the high cost of information and because accident or actuarial records become obsolete as innovations occur and product designs change, it would be quite expensive to have insurance provisions infinitely adjustable or to gear premium increases neatly to "defective" products and lawsuit costs. Because of these factors, we can say that liability insurance may dilute the effects of the trend toward making producers liable. ${ }^{74}$

\section{G. Are These Developments Revolutionary?}

Where do these trends affecting products liability leave us? There have clearly been many moves toward producer liability, both under tort and under warranty law. There has perhaps been a tendency to make larger awards. These moves may have been partially offset (in their impact on producers) by the growth of liability insurance. Still, as noted before, strict liability does not mean that the manufacturer or producer is liable for damages regardless of circumstances. First of all, the product must contain a "defect," and therefore "the manufacturer's strict liability depends on what is meant by defective."75 Arsenic in butter would be a defect, but cholesterol, while it may do harm, would not be regarded as a defect. The courts recognize that the availability of a product may provide more advantages than disadvantages, even though it can be misused or it may be "unavoidably

73 I am indebted to Professor Robert E. Keeton for discussing several of these issues with me.

74 Liability insurance itself may have important effects on resource allocation and on wealth distribution, but the subject here is the impact of the developments in products liability, given the existence of insurance and other institutions.

75 Traynor, The Ways and Meanings of Defective Products and Strict Liability, 32 TENN. L. REV. 363, 366 (1965). 
unsafe." Some writers draw the line at peculiar points-some seem to feel that only the highest quality item does anyone more good than harm. And the rationalizations are sometimes rather strange: hospitals are not held liable when a patient gets hepatitis from a blood transfusion because a transfusion is said to be a service rather than a product, or because hospitals are regarded as "bourns of mercy" and not as "profit-seeking vendors in the market place [like] General Foods, General Motors . . . "76 Nonetheless, as Coase suggests, ${ }^{77}$ the real reasoning, perhaps unconscious, may well be that the benefits from the decision are judged to outweigh the harm-that even risky merchandise such as a blood transfusion offers gain that should be weighed against the ill effects.

Producers may not be held liable if the "defect" poses hazards for only a few customers instead of for everyone. If only a small percentage of users develop allergic responses, the courts may regard the users, rather than the product, as being defective. ${ }^{78}$ As is true in all deviationfrom-the-norm tests, there is no neat criterion here: if a mechanical part ordinarily lasts three years, but the one in question failed in two and one-half years and resulted in injuries to someone, was the part defective? Should the producer be liable?

There are many problems, moreover, with proving that a defect existed or that it was attributable to a particular producer in the chain of component manufacturers, assemblers, or processors. The fact that an accident occurred does not show that a defect was present. If the user is clearly guilty of contributory negligence or if he knows of the defect and uses the product anyway, he may be unable to recover. And, according to Prosser, this inability to recover would be consistent with both warranty and tort law. ${ }^{79}$

Thus, in a number of situations, there are still many uncertainties about who would be liable. Neither producer nor consumer can proceed complacently by assuming that someone else will always be held liable. These recent developments may be revolutionary from the standpoint of the law, or in comparison with the slow pace of change in earlier periods, or as harbingers of things to come. On balance, though, it seems to me that the magnitude of the shift in liability

76 Id. at 368. Quotation is from Dibblee v. Dr. W. H. Groves Latter-Day Saints Hosp., 12 Utah 2d 241, 243-44, 364 P.2d 1085, 1087 (1961). The court went on to say, "No hospital gives green trading stamps ... or a car for one having the lucky blood purchase order number."

77 Coase, supra note 16 , at 19-27, where he examines statements by such authorities as Prosser and the language of several decisions in English and U.S. courts.

78 Traynor, supra note 75 , at 369 .

70 Prosser, supra note 36 , at 839.40 . 
assignment so far has not been dramatic. The main thing that has happened lately is a further modest increase in the probability that injured persons will be compensated by the producer.

\section{Possible Future Developments}

One future development that many envisage is simply the consolidation and completion of the shift toward strict liability. Some of the quotations in the preceding section indicate that a number of authorities believe that strict liability under tort will and should emerge. Justice Traynor is among those who have suggested the extension of such liability to physical damage to property (though still not to pecuniary or economic losses arising because the purchased item's quality falls short of the buyer's expectations): "The early cases limited strict liability to recovery for physical injuries to the person, but physical injury to property bears such close analogy to personal injury that there is no reason for distinguishing them." 80 Indeed, as Traynor then notes, "The Second Restatement of Torts would impose strict liability for physical damage to property as well as to persons." 81 Some have urged extension to bystanders. ${ }^{82}$ Some are hoping for improvements in the rules governing choice of law in products liability cases, which would somewhat reduce the uncertainties about the placement of liability. 83

Even if recent trends toward strict liability were consolidated and extended, however, it would still not be a very dramatic change. The crux of the matter would still be the necessity of proving the existence

80 Traynor, supra note 78 , at 373 .

81 Id., ciling Restatement (SECOND) of Torts \& 402A (Tent. Draft No. 10, 1964).

82 See Prosser, supra note 36, at 819-20.

83 See D. CAvers, The Chorce-of-Law Process (1965); Weintraub, Choice of Law for Products Liability: The Impact of the Uniform Commercial Code and Recent Developments in Conflicts Analysis, 44 TEXAs L. REv. 1429 (1966).

The uncertainties can be great. When an airplane manufactured in one state is flown by an airline whose main offices are in a second state, and the aircraft crashes in a third state, killing a passenger domiciled in a fourth state, there is a problem of choosing which state's law should apply. Present rules are sometimes said to yield predictability about whether the law will be that of the place of contracting, place of sale, place of performance, etc. But this is true only when the action is one based on contract (strict tort liability would probably call for the law of the "place of the wrong"). Besides, prediction is possible only after a particular accident has occurred. The applicable law is scarcely any more predictable, therefore, than the place or nature of the accident itself.

Choice of law often leads to capricious and surprising outcomes that seem unrelated to "justice." Many persons favor giving the courts more discretion to analyze the whole situation and choose the state law (as long as it has some "reasonable relation" to the accident) that would seem to yield the most equitable outcome in the particular circumstances. Extra discretion has its disadvantages, but some authorities evidently believe the gains would outweigh the costs. 
of a "defect" or (and this may amount chiefly to different language) the existence of a "duty" that was not fulfilled. As Prosser emphasizes, the issues about proof, abnormal use (a form of contributory negligence), intervening conduct, and knowledge of the defect (and therefore issues about representations and perhaps even about disclaimers) in effect still exist and relieve the producer of liability in many circumstances. ${ }^{84}$ Developments since Prosser's discussion-for example, the broader concept of a defect, the occasional shifting of the burden of proof, the higher probability of finding no defense in obviousness of peril-do not seem to alter the situation greatly. ${ }^{85}$ For these developments cannot reveal just how far the producer must go to carry out his "duty," and these issues about proof, abnormal use, and so on will still bear on decisions about whether a duty was neglected. Thus the full development of strict liability under tort would simply go a bit further to increase the chances that the producer will be held liable.

Some writers seem to have in mind more than strict tort liability, however, for they recommend or foresee more comprehensive compensation of victims than would occur under strict liability. One writer explicitly supports the abolition of the requirement of a defect. According to Cowan, "If this practice [applying strict liability as in Henningsen] grows, plaintiff may next be required only to connect up the injury with the product. He may not have to prove a defect. When and if this happens we shall have taken another step on the road toward making consumer's injuries into an equilibrium system, where the important question is not who caused the injury, but how shall the harm be repaired." 8 Numerous authors seem to have in mind rather drastic shifts in the spreading or allocation of losses. "The question central to the Santor-Seely dichotomy is whether the manufacturer may define the scope of his obligation, or whether the law should impose upon him the duty to allocate the risk as best he can, irrespective of any agreement between consumer and manufacturer."87 Frank-

84 Prosser, supra note 36 , at $824-48$.

85 See Hill, How Strict Is Strict? Have the Walls of the Citadel Really Crumbled?, 32 TExAs B.J. 759 (1969). For developments concerning particular issues, see Boland, Strict Liability in Tort for Transfusing Contaminated Blood, 23 ARR. L. REv. 286 (1969), and Note, Products Liability: Foreseeability of Unusual Uses of a Product Which Are Accompanied by Injury, 4 GA. L. REv. 164 (1969).

Page Keeton has urged that the producer should be liable if the product is sold "under circumstances that would subject someone to an unreasonable risk." Keeton, Products Liability-Inadequacy of Information, 48 TExAs L. REv. 398, 409 (1970). But it seems to me that essentially the same considerations would enter into deciding what was "unreasonable."

86 Cowan, supra note 53, at 1094.

87 Comment, supra note 58, at 1711. 
lin appears to think the future may hold more safety legislation or perhaps social insurance plans: "Today's tort law is heading toward protecting individuals from themselves.... [T] he fear was expressed in Henningsen that even though the buyer knew in advance that he was getting no protection (assuming no negligence liability) and that presumably the price of the product was lower because of this exculpation, the buyer would not or could not obtain commensurate, or even minimal, protection through private channels." 88

Justice Traynor explicitly mentions some possibilities that go beyond strict liability:

The development of strict liability for defective products, for industrial injuries covered by workmen's compensation, and for injuries caused by ultrahazardous activities, presages the abandonment of long-standing concepts of fault in accident cases. The significant innovations in products liability may well be carried over to such cases. On the highways alone injury and slaughter are not occasional events, but the order of the day, and sooner or later there is bound to be more rational distribution of their costs than is now possible under the law of negligence....

Any system of enterprise liability or social insurance designed to replace existing tort law as the means for compensating injured parties should provide adequate but not undue compensation. Only if reasonably adequate compensation is assured can the law justify closing traditional avenues of tort recovery. ${ }^{89}$

This passage appears to suggest some sort of auto compensation plan, ${ }^{00}$ or perhaps a social insurance scheme, for products liability cases in general. Such developments might have far-reaching consequenceswell beyond those of strict tort liability. The implications of some of these more dramatic changes will be discussed in subsequent sections. ${ }^{91}$

\section{The Implications Indicated by Economic ANalysis}

Let us try at this point to trace out the economic implications of alternative arrangements regarding products liability. In writing for

88 Franklin, When Worlds Collide: Liability Theories and Disclaimers in DefectiveProduct Cases, 18 STAN. L. REv. 974, 1011 (1966).

89 Traynor, supra note 75 , at 375-76.

90 The Keeton-O'Connell proposal is probably the most widely known auto compensation plan. See R. Keeton \& J. O’Connell, Basic Protection for the Traffic Victim (1965).

91 Some of the authors cited, and many other persons, are probably thinking of additional safety legislation-governmental constraints on the quality or design of products -but for the most part safety legislation and its implications are beyond the scope of the present paper. 
a variety of readers, I think it would be fruitless to plunge immediately into using the jargon and concepts of economics. Dreary though it may be, tracing out the basic notions of economics with the aid of arithmetic examples is surely preferable to a discussion that would have meaning for only a few readers. First, the basic ideas will be presented in their starkest form; the complications and qualifications will be considered afterward.

\section{A. General Background ${ }^{92}$}

To understand the economic implications of alternative policies, one has to have clearly in mind the notions of cost and comparative advantage; and to see how much and how little economics can guide one regarding policy, it is important to understand what is meant by "economic efficiency" and "Pareto optimality." Although it is a great oversimplification, let us confine our attention to three producers, each capable of producing two commodities. Any two commodities or services would illustrate the points, but let us label them automobiles and penicillin since the use of these items has often resulted in injuries. As is usually the case, the three producers (called A, B, and G) have different abilities to produce these items, as indicated in the following schedules.

TABLE 1

Production-Possibiliry Schedules

(Units of each commodity that could be produced per time period)

\begin{tabular}{|c|c|c|c|c|c|c|c|}
\hline \multicolumn{2}{|c|}{ A } & \multicolumn{2}{|c|}{ B } & \multicolumn{2}{|c|}{ C } & \multicolumn{2}{|c|}{$\begin{array}{l}\text { Combined Schedule for } \\
\text { the Three Producers }\end{array}$} \\
\hline Autos & $\begin{array}{l}\text { Peni- } \\
\text { cillin }\end{array}$ & Autos & $\begin{array}{l}\text { Peni- } \\
\text { cillin }\end{array}$ & Autos & $\begin{array}{l}\text { Peni- } \\
\text { cillin }\end{array}$ & Autos & $\begin{array}{l}\text { Peni- } \\
\text { cillin }\end{array}$ \\
\hline 9 & 0 & 12 & 0 & 3 & 0 & 24 & 0 \\
\hline 6 & I & 10 & 1 & 2 & 1 & 23 & 1 \\
\hline 3 & 2 & 8 & 2 & I & 2 & 22 & 2 \\
\hline \multirow[t]{5}{*}{0} & 3 & 6 & 3 & o & 3 & 21 & 3 \\
\hline & & 4 & 4 & & & 19 & 4 \\
\hline & & 2 & 5 & & & 15 & 6 \\
\hline & & 0 & 6 & & & 9 & 9 \\
\hline & & & & & & 0 & 12 \\
\hline
\end{tabular}

These schedules show the combinations of the two commodities that each producer can produce-the largest amount of autos that each can produce for any given quantity of penicillin he produces (or, alternatively, the largest amount of penicillin that each can produce for any given number of autos that he produces). For instance, if $\mathrm{A}$ de-

92 For a clear presentation of the central points here, see also A. ALchIAN \& W. ALIEN, UNIVERSTTY ECONOMIS 163-95 (2d ed. 1967). 
votes all his time to producing autos, he can produce 9 per year; if he produces 1 unit of penicillin, the time and resources left over will permit him to produce only 6 autos; if he produces 2 units of penicillin during the period, he can produce in addition only 3 autos; or by giving all his effort to the production of penicillin, he can produce 3 units. Note that $\mathrm{A}$ has to sacrifice 3 autos whenever he wishes to produce an extra unit of penicillin. The economist says that the marginal cost of penicillin to $A$ is 3 autos-that is, whatever must be sacrificed in order to have an incremental or "marginal" unit of penicillin. Conversely, the marginal cost of autos to $A$ is $1 / 3$ unit of penicillin; to increase his output of autos by 3 , he has to give up 1 unit of penicillin, or to increase his output of autos by 1 , he has to sacrifice $1 / 3$ unit of penicillin.

$B$, however, must give up only 2 autos to produce an extra unit of penicillin, and has to sacrifice $1 / 2$ unit of penicillin to produce an additional car. To $\mathrm{C}$ the marginal cost of penicillin is $\mathrm{I}$ auto, and the marginal cost of autos is $I$ unit of penicillin. Note that $B$ has an absolute advantage over $\mathrm{G}$ in producing either autos or penicillin-he is capable of producing 12 autos (if he devotes all his energies to that output) or 6 units of penicillin (if he devotes all his effort to that output), while the most that $\mathrm{C}$ can produce is 3 autos or 3 units of penicillin. Yet $C$ would have to sacrifice only $I$ auto, while $B$ would have to give up $\dot{2}$ autos, to produce a unit of penicillin. According to the economist's jargon, $\mathrm{G}$ has a comparative advantage in producing penicillin, while $\mathrm{B}$, relative to $\mathrm{C}$, has a comparative advantage (as well as an absolute advantage) in producing autos. This merely makes precise the common sense realization that, even if a lawyer is a better typist than his secretary, she has a comparative advantage in typing because his productivity in professional activities is so much greater than his secretary's.

Given these production possibility schedules for A, B, and C, who should produce autos and who should produce penicillin? If we want to have the maximum output of one commodity, given whatever amount of the other commodity is desired, we should always turn first to the producer who has the comparative advantage in producing that commodity. And for additional output of any commodity, we should always turn to the producer who at that point has a comparative advantage (or, in other words, who can produce additional units at the lowest marginal cost).

In the illustration, if people did not have any use for penicillin at all, it would of course be desirable to have $A, B$, and $C$ all produce only autos, and they could turn out a total of 24 autos per period. Suppose 
now that 2 units of penicillin are desired. The efficient thing to do is to turn to $\mathrm{G}$, the low cost producer of penicillin. If he produces the 2 units of penicillin, only 2 autos must be sacrificed, and the community can still have 22 autos as well as the 2 units of penicillin. If we turned to $B$ for the 2 units of penicillin, 4 autos would have to be sacrificed, leaving total output at 20 autos and 2 units of penicillin. If we turned to $A$ for the 2 units of penicillin, we would sacrifice 6 autos, which would put total output at 18 autos and 2 units of penicillin. By turning to $\mathbf{C}$ instead of $B$ or $A$, total output can be larger. In that circumstance, someone can be made better off without making anyone else worse off.

Suppose 6 units of penicillin are desired. C's maximum output is 3, so for the additional 3 units we must turn to another producer. The one to whom we should turn is the next-lowest-cost producer-the one who at that point has a comparative advantage in producing penicillin. As noted earlier, the marginal cost of penicillin if $A$ produces it is 3 autos, while the marginal cost if $B$ produces it is 2 autos. $B$ has the comparative advantage in producing the extra 3 units of penicillin. By turning to him, we can have the 6 units of penicillin and still have 15 autos ( 9 produced by $A$ and 6 by B), while if we turned to $A$ instead of $B$, we would end up with 6 units of penicillin (produced by $C$ and A) and only 12 autos (produced by $B$ ).

If we trace out the maximum number of autos that can be produced for each quantity of penicillin that might be desired, we derive what the economist calls the combined production-possibility schedule (parts of which are indicated in Table 1) or the output combinations that constitute "economic efficiency" or the "set of efficient points." At one of these efficient points, it is impossible to expand the output of autos without reducing the output of penicillin (or to expand the output of penicillin without reducing the output of autos). At an inefficient point, it is possible to expand the output of one commodity without reducing the output of another. At an inefficient point there is thus some kind of adjustment that can be mutually advantageous-a deal that some persons have an incentive to make because they could themselves be better off without anyone else objecting.

Let us turn back, for example, to the situation in which someone in the community was willing to pay the cost of 2 units of penicillin. Assume that this person is willing to pay 7 autos for the 2 units (but only 1 auto for a third unit). Any one of the producers would find it advantageous to produce the 2 units of penicillin. A would have to reduce his output by 6 autos but could sell the 2 units of penicillin for 7 autos. (In this simple economy autos serve as money, and people 
have stocks of this money for trading purposes quite apart from this year's output.) $B$ and $\mathbf{C}$ could produce the 2 units of penicillin by sacrificing only 4 and 2 autos respectively. Suppose the buyer actually got together with $A$ and offered 7 autos, which, as noted earlier, would be an inefficient solution. If getting together and negotiating involved zero costs, $\mathbf{C}$ would soon offer to sell the 2 penicillin to the buyer for between 2 and 4 automobiles. He would not sell at a price of less than 2 automobiles, because he has to give up 2 automobiles to produce 2 units of penicillin. He could not charge more than 4 autos, for $\mathrm{B}$ would then find it advantageous to make the sale, eliminating any gain for $\mathrm{C}$. At any price between 2 and 4 autos for 2 units of penicillin, $\mathrm{C}$ and the buyer would both be better off than they would be if the buyer bought penicillin from $A .{ }^{93}$ They could even arrange to give 1 auto to $A$, and leave no one worse off than before. The reason is simply that there are 4 extra autos to be shared among $\mathrm{C}$, the buyer, and $\mathrm{A}$. Thus, voluntary exchange takes the community to an "efficient point"-in this instance, to the point where the community's total output is 22 autos and 2 penicillin units rather than 18 autos and 2 penicillin.

This is quite important to remember. If the economy is at an inefficient point, there is an opportunity for a mutually advantageous deal. This will shift each output to whatever producers have a comparative advantage in producing it and thus yield a net increment in total output. This increment can be parceled out by the bargain so as to make the bargainers better off without making anyone else worse off. This possibility provides the incentive to make the deal. The existence of a mutually advantageous trade implies, it should be noted, that the gains exceed the transaction costs-that is, the costs connected with the trade. These include the costs ${ }^{94}$ of gathering information about the products and about where to buy them, of negotiating and drawing up contracts, and of enforcing the contracts (including the implied property rights to keep and use whatever the parties traded for).

Such bargains will occur if the transaction costs are covered (and if people make use of voluntary exchange rather than coercion). If the bargaining costs would exceed the gains, there could be no increment in output to parcel out, and no deal would be effected. In that event, though, the so-called "inefficient solution" (in our example, buying from A so that output is 18 autos and 2 penicillin units) is the best that

93 $\mathbf{C}$ and the buyer would also be better off, and total output higher, than if the buyer purchased from B, since B could produce the 2 penicillin only by sacrificing 4 autos.

94 As will be noted later, there may also be psychic costs of making a direct open deal, if exposing the terms would make it distasteful in most persons' eyes. 
can be achieved through voluntary exchange, that is, in a way which assures that no one is being made worse off. ${ }^{95}$ This inefficient solution may in fact be the most efficient attainable solution. The government might find some way to reduce the bargaining costs, but whether it can do so is difficult to ascertain, because the government's action is almost certain to involve compulsion for some persons, and one cannot be sure what the true costs of the action are.

Of course the government might simply direct that 22 autos and 2 penicillin units be produced, and thus set production at an efficient point; but it should be kept in mind that the government too would encounter information, decision-making, and enforcement costs. With production no longer organized by voluntary exchange, we would lose the information generated by markets and the incentives provided by exchange opportunities to acquire information, identify favorable deals, and take action. Government would find some slippage between good intentions and actual outcomes. It might decree that producers make 22 autos and 2 penicillin units, yet actually obtain 15 autos and 1 penicillin.

Moreover-another background item for later use-this possibility of government decree instead of voluntary exchange highlights a distinction between the set of "efficient points" and a more restricted kind of efficiency that the economist calls "Pareto optimality." (This rather awkward term is named after a nineteenth century social scientist who figured out this concept after grappling with the question: "What does one mean by optimality for a group?") To keep the meaning of this term within reach, one might think of it as "the results, or simulated results, of voluntary exchange." As the discussion and Table 1 have indicated, there are many efficient points, not just one. The government could say, "Autos are bad for you, and production next year will be zero autos and 12 units of penicillin." That would certainly be one of the "efficient points," for there would be no way to expand the output of autos without sacrificing some penicillin. But it might be an output combination that had little relationship to the preferences of many consumers and little similarity to the output combination to which voluntary exchange would lead. Starting with a particular distribution of wealth, voluntary exchange would lead to one particular efficient point-say, 22 autos and 2 penicillin (or rather one particular most-efficient-attainable point). Starting from a different distribution of wealth, voluntary exchange would lead to a different efficient point-say, 15 autos and 6 penicillin. If I had

os Only voluntary exchange can assure that no one is worse off and that the information about relative values is correct. The use of compulsion leaves this in doubt. 
considerable wealth, I might be willing to pay a great deal for autos and not much for extra penicillin, while if you had that wealth you might prefer to trade a great deal for extra penicillin but relatively little for extra autos. These trading preferences would help determine where we ended up on the combined production-possibility-schedule in Table 1.

Thus there are two related but not identical concepts of efficiency"economic efficiency," in which no output can be expanded without reducing some other output, and "Pareto optimality"-particular efficient points to which voluntary exchange would lead, and at which no person can be made better off (as he himself sees his well-being) without making someone else worse off (as he himself sees his wellbeing).

The same principles described above with respect to autos and penicillin apply to other outputs. They apply to intermediate outputs in the production process, such as windshields and tires that are components of the automobiles. Simply substitute "windshields" and "tires" for "autos" and "penicillin" in Table 1. Voluntary exchange will put the production of each in the hands of producers having a comparative advantage in producing each item. Or, substitute "information" and "other goods" for "autos" and "penicillin." If the travel agent can produce travel "information" at a lower sacrifice of "other goods," that is, at a lower marginal cost, than you and I, it will pay us to make a mutually advantageous deal: you and I hire him to compile information in a central location; he hires us to produce other goods; and we split the net increment in the value of total output. If consumers can unearth the information about the way to use a hammer at lower cost than the hammer manufacturer can provide it, the manufacturer will hire the consumer to get the information (for example, he lowers the price a nickel instead of printing instructions). Or, to look at the other side of the coin, the consumer induces the manufacturer to leave this information acquisition in the hands of the consumer; he does this by refusing to pay enough extra for hammers with instructions to cover the cost of printing the instructions. In effect, the manufacturer can make a greater profit without the instructions than with them.

If there were zero transaction costs, and if people eschewed the use of coercion or interference with voluntary exchanges, it would not matter, as far as resource allocation is concerned, how the legal rights or liabilities were initially assigned, that is, whether the purchaser or the manufacturer was liable for injuries and damages. The classic 
analysis of this matter is that of Ronald Coase. ${ }^{98}$ There has been some debate about whether Coase's conclusion applies to the long run. ${ }^{97}$ One might think, for example, that manufacturer liability would reduce the industry's profits, causing resources in the long run to move elsewhere. If this was inefficient, however, some "gravy" could be obtained by bringing about the correct allocation of resources. It would pay some persons, if transaction costs were zero, to make deals that would do this. Presumably consumers, by making side payments, would hire entrepreneurs to stay in the right industries. There now seems to be general agreement that Coase is right if one accepts the basic assumptions. ${ }^{98}$

Perhaps it should be stressed here, as well as later, that these assumptions are fairly heroic. We know that, like any other assumptions used to simplify and think about reality, they do not hold in the real world. There are transaction costs (indeed it is difficult to visualize such a world and to adhere to the assumption just for the purpose of analysis). Furthermore, many persons are unwilling to abide by the results of voluntary exchange. Most of us have a taste, at least occasionally, for using coercion or for interfering with other persons' choices. These points will be discussed more fully later. For the moment I wish merely to stress that, as Coase recognized, the situation he discussed is simply a point of departure (as is the auto-penicillin example). But it pays (I assert) to understand the oversimplified situation before trying to make judgments about the more complex ones.

Consider another perhaps unconventional output-risk bearing. If my business is "wildcatting" for oil or dealing in second mortgages and I find the risks sufficiently distasteful, I will sell off the assets and rights involved to some vigorous person who finds the risks less distasteful. That is, we make a mutually advantageous deal in which he takes over the risk bearing, and I shift into some other business that I regard as preferable. Voluntary exchange puts the risk bearing on the shoulders of the person with a comparative advantage in bearing it.

Consider finally one of the principal commodities to which this report pertains-“injury prevention." Let us consider the hypothetical

06 Coase, supra note 16, at 1 . See also Demsetz, The Exchange and Enforcement of Property Rights, 7 J. LAw \& Econ. 11 (1964).

97 Calabresi, The Decision for Accidents: An Approach to Nonfault Allocation of Costs, 78 HARv. L. REv. 713 (1965).

98 Nutter, The Coase Theorem on Social Cost: A Footnote, $11 \mathrm{~J}$. LAw \& Econ. 503 (1968); Calabresi, Transaction Costs, Resource Allocation and Liability Rules-A Comment, 11 J. LAw \& Econ. 67 (1968). 
production-possibility schedules of Auto Drivers and Auto Producers, using "broken arms prevented" as one commodity, and "other goods worth $\$ 100$ per package" as the other commodity. By being more careful, using buses more and cars less, choosing safer but more timeconsuming routes, fastening safety belts, or reducing the frequency with which teen-age children are allowed to drive, auto drivers can produce "broken arms prevented," but it consumes time and reduces their output of other goods. By installing various safety features, such as governors that would keep speeds down to 25 miles per hour, auto manufacturers too can produce "broken arms prevented," but it would consume resources and reduce their output of additional or improved automobiles (a maximum speed of 25 miles per hour would reduce other people's outputs too).

TABLE 2

More Production-Possibitity Schedutes

(Combinations that could be produced per time period)

\begin{tabular}{|c|c|c|c|c|c|}
\hline \multicolumn{2}{|c|}{ Auto Drivers } & \multicolumn{2}{|c|}{ Auto Manufacturers } & \multicolumn{2}{|c|}{ Combined Schedule } \\
\hline $\begin{array}{l}\text { Broken } \\
\text { Arms Pre- } \\
\text { vented }\end{array}$ & $\begin{array}{l}\text { Other Goods } \\
\text { (Packages } \\
\text { Worth } \\
\text { \$100 Each) }\end{array}$ & $\begin{array}{l}\text { Broken } \\
\text { Arms Pre- } \\
\text { vented }\end{array}$ & $\begin{array}{l}\text { Other Goods } \\
\text { (Packages } \\
\text { Worth } \\
\$ 100 \text { Each) }\end{array}$ & $\begin{array}{l}\text { Broken } \\
\text { Arms Pre- } \\
\text { vented }\end{array}$ & $\begin{array}{l}\text { Other Goods } \\
\text { (Packages } \\
\text { Worth } \\
\$ 100 \text { Each) }\end{array}$ \\
\hline $\begin{array}{l}\mathbf{5} \\
4 \\
3 \\
0\end{array}$ & $\begin{array}{l}0 \\
1 \\
2 \\
3\end{array}$ & $\begin{array}{l}4 \\
3 \\
2 \\
0\end{array}$ & $\begin{array}{l}0 \\
3 \\
5 \\
6\end{array}$ & $\begin{array}{l}9 \\
8 \\
7 \\
6 \\
5 \\
3 \\
0\end{array}$ & $\begin{array}{l}0 \\
3 \\
5 \\
6 \\
7 \\
8 \\
9\end{array}$ \\
\hline
\end{tabular}

In this example we have departed from the assumption of constant marginal cost for each type of producer. Here it is assumed that, starting from zero output of broken arms prevented, drivers can produce 3 by sacrificing only 1 unit of "other goods," only 1 more by sacrificing a second unit of other goods, and only 1 more by sacrificing all other goods. In other words, the first few broken arms prevented could be produced by exercising moderate care, but additional units require greater and more costly adaptations. Manufacturers, in this imaginary instance, could produce 2 broken arms prevented by sacrificing only 1 unit of other goods, one additional prevention by sacrificing 2 units of other goods, and a fourth prevention per period only by sacrificing 3 more units of other goods. Initially, it is assumed, simple safety features yield improved results, but to reduce the hazard further and further, the autos must be made quite cumbersome and 
costly. How much damage prevention (broken arms prevented) is desired in total depends upon the amount of other goods one believes should be sacrificed to reduce injuries. One might prefer leaving this up to the bids of individuals, or one might prefer to interfere with individuals' choices and have, say, the majority adopt a rule. For the moment, in any event, our concern is with this question: who should produce whatever output of broken arms prevented is desired? Suppose the community is willing, as shown through either market bids or the political process, to pay the cost of only 3 broken arms prevented. For that amount, if we wish to maximize total output, we should turn to the auto drivers. And, if negotiation costs are low, drivers will hire manufacturers not to install safety features (or manufacturers would bribe drivers to produce the injury prevention). Transaction costs might be low in this instance if the matter were left to the market, for negotiation would consist of drivers being unwilling to pay manufacturers a price that would cover the safety features, since the drivers themselves could produce 3 broken arms prevented at a lower sacrifice. By having the drivers produce this amount, there would be an extra 2 units of "other goods" that drivers and manufacturers could share.

Suppose next that the community wished to live less dangerously and showed a willingness, either through market bids or the political process, to buy 5 broken arms prevented per period. According to Table 2, the manufacturers should be induced to produce the extra 2 broken arms prevented, because they could do so at a cost of 1 unit of other goods, putting total output at 5 broken arms prevented and 7 "other goods." If drivers produce all 5 broken arms prevented, total output of "other goods" drops to 6 . This is an inefficient point, and a mutually advantageous deal can be made. If information acquisition is cheap, drivers will soon see that it would be economical to hire the manufacturers to produce safer automobiles (by paying them the higher cost), and manufacturers will soon see that it would be profitable to hire drivers to produce more other goods instead of the 4th and 5 th broken arms prevented (by offering to sell them safer automobiles).

The above instance involved a special relationship between the two producers. One was the seller of a product, the other was the consumer of the product, and the use of the product resulted in injuries to the consumer. The same principles hold, however, if no special relationship exists. For "Auto Drivers," we could substitute "Third Parties Whose Arms Are Broken When Autos Are Used," or "Piano Tuners Whose Ears and Businesses Are Damaged by the Noise Made by Truck- 
ing Firms." or "Piano Tuners" were in fact taking steps to reduce injuries when Auto Manufacturers (who sell their product to various users including trucking firms) had a comparative advantage in producing that much injury reduction. That is, by modifying the product, the manufacturer could provide this damage reduction at a lower cost. If transaction costs were zero, it would pay the Third Parties or Piano Tuners to make a deal-to cease the costly steps they were taking (for instance, avoidance of major streets by Third Parties, or construction of soundproof shops by Piano Tuners) and hire the Auto Manufacturers to make the modifications that would reduce the injuries. Alternatively, the Auto Manufacturers would offer to sell this new output, the designated amount of damage reduction, to the Third Parties or Piano Tuners at prices lower than the latter were currently paying, and yet make a profit on the deal.

Thus the principles involved are the same ones that applied when the two producers of injury reduction had a seller-customer relationship (though, as will be seen later, the magnitude of negotiation costs may vary greatly with these different relationships). Also, of course the principles involved are the same ones discussed initially with reference to producers of autos and penicillin. I have belabored these matters because they are so essential in trying to see certain implications of alternative products liability arrangements. In summary, if we wish to reach an efficient point, we should seek arrangements in which each output is produced by those having a comparative advantage in producing it. If transaction costs were zero, voluntary exchange could lead to a particular efficient point, depending upon the initial wealth distribution. But we must turn now to some of the complications (including the fact that logic does not compel one to prefer economic efficiency or Pareto optimality over all other situations!).

1. Implications of Transaction Costs. Unfortunately, even if we could agree on economic efficiency as a goal, the best arrangement of liability is not completely clear when there are transaction costs. In many instances these costs not only exist but are large. Consider the reduction of injuries and damages caused by the noise of autos and trucks. For the sake of brevity I shall call this output noise abatement. Voluntary exchange does not lead the economy to what would be an efficient point in the absence of negotiation costs. Almost everyonenot only piano tuners-would attach value to noise abatement. In the

99 Although some of these examples stray to some extent from the category of "products liability" toward other types of liability cases, they serve to bring out the relevant points. 
aggregate they would presumably be willing to sacrifice quite a bit to induce manufacturers to design quieter vehicles (and to induce users to drive more quietly). Bargains would lead to the production of noise abatement by the parties having a comparative advantage in its production, taking the economy toward an efficient point. But negotiation costs are high enough to prevent much exchange: without a market it is extremely expensive for people to get together and find out how much in total they would pay for various increments in noise abatement. For this particular output, it would be costly to exclude "free riders" from using the product without paying, costly to enforce contracts between the individuals who bought noise abatement and the drivers and auto manufacturers who were to supply noise abatement, and therefore costly to determine how much the users would be willing to pay. Even apart from the difficulty of excluding non-payers, it would be extremely expensive to negotiate millions of contracts between the various parties affected, particularly since autos and trucks move about among localities, producing the noise in diverse, unpredictable locations. How much simpler it would be if each person could go to the store and buy whatever number of cans of noise abatement he desired.

Should one throw up his hands and say: We must be at the most efficient attainable point, since because of these transaction difficulties further deals cost more than the results are worth to the individuals affected? The answer, unfortunately, is not clear. Even if it is too costly for voluntary groups to form and make further bargains, we belong to another group, government, and, even if my objective is economic efficiency, I may without being illogical prefer to have government intervene. By using some compulsion, a governmental unit can take action, requiring automobile manufacturers and drivers (or piano tuners and other sufferers) to make certain adaptations. Government could provide for punishment, through civil or criminal proceedings, if the rules were violated. In contemplating such a step each of us has to make a personal judgment about the gains and costs, in terms of reaching an efficient point (and in terms of his own utility function). Personal judgments have to be made because, with information about the consequences being expensive and with some compulsion and no market, the costs and gains are far from clear.

In some instances of intervention, for example, requiring mufflers and making people liable for "unreasonable nuisances," most people agree that the gains outweigh the costs. In other instances, such as requiring silent engines or making women liable for the distress they inflict on others by wearing maxi-skirts, most people agree that the 
costs would outweigh the gains. In many instances, however, disagreement exists and is not necessarily illogical-even in terms of reaching an efficient point-because accurate information is so expensive and personal judgments are involved. The most that economic analysis can do to help is to try to provide better information (whenever the prospective gains from this activity are judged to exceed the costsl).

This general conclusion applies, unfortunately, to the policy suggestions pertaining to products liability. If there were zero transaction costs, it would not matter as far as economic efficiency is concerned (though it would matter from the standpoint of each person's conception of fairness) whether producers or consumers were required to bear the damages. Ensuing bargains would assign each increment of injury prevention to the party having a comparative advantage in producing it, and would take us toward an efficient point. Information, contracting, and policing costs are not zero, however, and there will be room for disagreement about whether particular forms of government intervention would bring improvements or "disimprovements."

2. Is Economic Efficiency or Pareto Optimality Good? Thus far, the discussion has assumed that we agree upon either economic efficiencymaximum output of each product, given the outputs of the others-or Pareto optimality-the particular efficient point to which voluntary exchange would lead starting from a particular distribution of wealth-as our objectives. Are these good things which we can agree upon as objectives? Although it seems plausible that we should wish to maximize output, there is no reason that all individuals should agree upon economic efficiency or Pareto optimality as the supreme objective.

First, economic efficiency must be defined either in a static sensewith tastes, information and technology considered to be given-or in a rather vague imprecise sense, in which the outputs include the production of information, taste changes, and technological advances. If defined in the latter sense, the production of knowledge and improved technologies are probes into the unknown; one cannot define the unknown outputs or the costs and gains from steps to produce them; and therefore one cannot satisfactorily define the set of efficient points. If economic efficiency is defined in the static sense, on the other hand, it may well be sensible to sacrifice some of that kind of efficiency for the sake of advances in knowledge and technology. ${ }^{100}$ Most people feel that some form of patent law to shelter inventors from competition

100 Demsetz reminds us of this in Information and Efficiency: Another Viewpoint, 12 J. LAw \& ECoN. 1, 19-20 (1969). See also McKean \& Minasian, On Achieving Pareto Optimality-Regardless of Cost, 5 WESTERN ECON. J. 14 (1966). 
is desirable, and many people feel that a modest degree of monopoly power to shelter other innovators is desirable. In both situations, economic efficiency in the static sense is being sacrificed for the sake of technological development. In connection with products liability, one might approve making unsafe products more (less) expensive than voluntary exchange would make them in order to stimulate research on how to make safer products (or how to use products more safely). Or one might approve sheltering the inventor of safer products to stimulate such inventions, even though dissemination of this safer design to other producers was retarded.

Second, if we consider those particular efficient points that are Pareto optimal, they are not necessarily ones that you and I could agree upon as objectives. Voluntary exchange leads to a point where no one can be made better off as he sees his well-being without making someone else worse off as he sees his well-being. In other words each person is allowed to decide what trades he wishes to make. Reaching a Pareto-optimal point implies letting each person decide what is good for him. To a very tolerant person (or to a far-sighted person who is worried about the possible repercussions if his group uses the political process to tell others what is good for them), this objective may be appealing. But all of us are accustomed to deciding what is good for children, and most of us are perfectly willing to decide occasionally what is good for other adults, even if their behavior will not have any "tangible" spillover effects on us. Thus we are tempted to prescribe what kinds of literature people should not read, what they should not drink, and what risks they should not be allowed to assume. The choices of other individual's sometimes cause us pain, even if they do not affect us in any physical way; and logic does not compel individuals to prefer policies that would take the economy toward Pareto-optimal efficient points. ${ }^{101}$ If logic does not compel one individual to prefer Pareto optimality, it does not compel a majority of voters to so prefer.

Third, one may reject Pareto optimality-that is, simulation of the results of voluntary exchange-because he attaches value to a particular decision-making procedure, such as majority rule, or to some unconventional output that is not included in our usual conception of product possibilities, such as cohesiveness or social stability. Like the other possible reasons for rejecting Pareto optimality, this considera-

101 Some have redefined Pareto optimality to allow for "interdependence of utility functions" or tastes for interfering with the choices of others, but this yields a new type of boundary that has ambiguous properties and gives little operational guidance. Thus, Pareto optimality-no matter what items are counted as outputs-can help one think about criteria and the effects of policies but cannot give specific guidance. 
tion may explain why some persons prefer product liability arrangements that are not conducive to economic efficiency (narrowly conceived).

Fourth, quite apart from the preceding points, any individual may prefer an inefficient point to an efficient one if he believes he can twist the distribution of wealth in the direction he desires at less transaction costs (to him) than he would incur if he tried to do it through an overt tax or subsidy. Consider the minimum wage, which makes it relatively expensive for the employer to hire workers with low productivity (for example, handicapped, old, teen-age, poorly educated, inexperienced, or "undesirable" workers). Employers will find it economical to substitute, to some extent, skilled labor or machines for the low-productivity workers. This process increases the demand for skilled labor and certain machines, raising their rates of hire, and benefiting the owners of these resources at the expense of the handicapped workers (or, if the handicapped are given relief, at the expense of the general taxpayer). Skilled laborers or machinery producers may like the minimum wage, even though it puts the economy at an inefficient point.

Why don't these laborers or producers strike a bargain with the unskilled that is mutually advantageous? If the handicapped workers were allowed to work, there would be an increment in output that could be shared among skilled laborers, machinery producers, formerly unemployed workers, and taxpayers-making everyone better off. Why don't these groups get together, have the minimum wage law repealed, and arrange either a contractual split of the extra output, or taxes and subsidies that would take part of the gains away from the handicapped (or the taxpayers, if they now finance less relief), and restore the rewards accruing to the skilled workers and machinery producers? The answer is, of course, that transaction costs are too high. This deal would even involve psychic costs, because few would have the gall to urge overtly such a bargain with the handicapped. In addition, it would require enormous resources to go through the political bargaining involved in repealing such a law and the political or contractual negotiations involved in recapturing much of the gains. The skilled worker's preferred course of action, therefore, is to support the minimum wage law (and convince himself that his intention is to help the poor). As before, if an individual can feel this way without being illogical, there is nothing surprising about a majority feeling this way.

This point is important with respect to products liability. A person may understandably prefer some "deep pocket" (that is, "soak the rich") arrangement even if it sacrifices efficiency, because transaction 
costs might make it more expensive to him to effect the same wealth distribution through some arrangement that was consistent with economic efficiency. Incidentally, despite the selfish attitude depicted in my minimum wage example, one may attach great value to affecting wealth distribution in an altruistic way; a person who does not stand to benefit may attach value to a more equitable distribution of wealth or to a bonus for innocent bystanders who are injured. Whatever redistributions of wealth one may regard as fair or desirable, he may logically judge that he can obtain these redistributions at lower cost to him by advocating a measure that impairs economic efficiency than by pressing for a package of measures that would not reduce economic efficiency.

Moreover, it appears that a major consideration pushing the courts toward strict liability has been concern for fairness or equity. Advocates of the "deep pocket" doctrine seem to believe that other consequences of assigning liability are not as important as putting the burden on those having the greater ability to pay. Repeatedly one encounters the following sort of statement: "The cost of an injury and the loss of time or health may be an overwhelming misfortune to the person injured, and a needless one, for the risk of injury can be insured by the manufacturer and distributed among the public as a cost of doing business."102 The same consideration underlies some of the opposition to strict liability: "General Motors in its role as a consumer of automotive parts hardly needs absolute liability in tort to pass on the risk of loss to a smaller vendor of component parts."103 There has been less concern about the possible effects of revised liability assignment on the efficiency of resource allocation.

While confessing to the absence of a generally valid criterion of optimum policy, I might add a word about the role of prices in measuring outputs. In the first hypothetical example, I used physical outputs, autos and penicillin. On these circumstances the measurement of cost is clear. As soon as I proceeded to a slightly more complex situation-"broken arms prevented" and "packages of other goods worth $\$ 100 "$-I had to introduce a package or aggregate in which prices served as weights. The cost of a broken arm prevented was so many packages worth $\$ 100$ - say, two cameras at $\$ 30$ each and two electric blankets at $\$ 20$ each. If one approves the particular mixture of voluntary exchange and government intervention that results in

102 Escola v. Coca-Cola Bottling Co., 24 Cal. 2 d 453, 462, 150 P.2d 436, 441 (1944) (Traynor, J., concurring). Or see Prosser's views in HandBook of THE LAW of ToRTs 22 (3d ed. 1964).

103 Comment, supra note 58, at 1714. 
these prices, then he approves their use as weights. If some individuals do not approve of this mixture, they need not approve of these weights and, therefore, of the measure of marginal costs. In that case people can disagree endlessly about what is efficient in terms of their particular "utility functions" or their particular concepts of a "social welfare function." Logic does not then compel different individuals to agree on a criterion; in fact it compels the group to be at sea without a rudder (until the costs of disagreement induce them to agree upon some procedure or criterion).

Simply stated, there is no inherently correct criterion of public policy regarding products liability or anything else. Blum and Kalven are right when they say:

In the situation in which his [the economist's] analysis is most refreshing [where zero transaction costs exist], the economist tells us that the liability issue is not worth arguing about....; and in the other situation, where he stresses that the legal rule does affect the allocation of resources, his analysis at best yields indecisive clues as to the proper answer. ${ }^{104}$

3. Where Does This Leave Us? Although economic analysis can yield only indecisive clues as to the proper policies, this aid should not be discarded casually. After all, none of the sciences can do more to assist public policy. Chemistry and physics can only provide information-indecisive clues-bearing on certain decisions; they cannot tell one what ought to be done. Yet the information they provide is often important to anyone trying to choose among alternative courses of action. There is no escape from making personal judgments-about uncertain consequences of actions and the importance or value of those consequences. But information can help. Economic analysis can indicate at least the direction of certain effects of alternative products liability arrangements.

The principal basis for predicting effects of policies is the economist's basic tool-the downward sloping demand curve. This tool says simply that, the more expensive an item or action is, the less of it individuals will demand. Or, alternatively, the less one must sacrifice to have a unit of an action or commodity, the more of that action or commodity one will decide he needs. Non-economists often doubt this proposition. Without reflecting about the matter very much, they conclude that an individual or a group needs a particular unique quantity of water or classrooms or penicillin or gasoline. They ap-

104 W. Blum \& H. Kalven, JR., Public Law Perspectives on a Private Law Problem: auto Compensation Plans 65 (1965). 
parently doubt that people can substitute other things for such services. Yet other things can be substituted in order to find preferred positions, even though the process may involve subtle or complex adaptations. If the cost of gasoline went up to fifty cents per gallon in the United States, people would eliminate a few marginal trips, use car pools a bit more, substitute some bus and air travel for automobile trips, use delivery services more, shift in some instances to smaller vehicles that used less fuel per mile. If the cost went up to two dollars per gallon, automobile manufacturers would find it profitable to redesign engines, drivers would calculate their routes more carefully, and businesses would use rail shipments and make numerous other adjustments. If the cost went up to ten dollars per gallon, locational patterns would gradually be affected, and cities might even become rapid transit cities rather than sprawled out automobile cities. ${ }^{105}$

Similarly, if products liability laws make a type of product or action more expensive, people will find ways to take less of that item and substitute others. I recognize that many people doubt this proposition where an action already involves as a cost the risk of death or injury. For instance, it is often contended that a financial burden to be borne by the careless driver or careless user of a product would do nothing to deter his lack of caution because the threat of injury or death or, in some instances, criminal punishment, would already provide the maximum deterrent effect. ${ }^{108}$ Who is going to be careless if the result would be injury? Who would be any less careless if the result would be injury plus a financial penalty? I believe that those who make this contention are often thinking of the deterrent as being a 100 per cent probability of death or serious injury. What one realistically faces when he is a little less careful, however, is a relatively small increase in the probability of injury or criminal punishment, and we constantly trade small increases in the probability of catastrophe for other things that we want. Most of us sometimes cross busy streets at dusk or drive cars in rainy weather, accepting a higher probability of being killed in exchange for a saving of time or some other desirable good. Small increases in the probability of death or injury do not seem to be "maximum deterrents." If one adds a financial cost to a small increase in the probability of being killed, it may be a significant increase in the total cost. If one adds a one in a hundred chance of losing two hundred

105 Even the popularity of miniskirts in Britain was partly a response to the law of demand (and in part a subsequent change in tastes): miniskirts were relatively inexpensive because Britain's $12 \%$ sales tax did not apply (until November 1, 1968) to skirts shorter than 24 inches from hem to waistband.

108 See, e.g., L. Green, Traffic Victims: Tort Law and Insurance 95 (1958). 
dollars in the form of higher insurance premiums to a one in a hundred chance of having an arm broken, it may be a significant addition to cost.

Since most of our decisions involve small changes in the probability of serious injury, there is no reason that the law of demand should not apply, that is, that extra costs should not deter. The magnitude of the response will depend on circumstances; it can be determined only by observing the facts, and none of us knows with certainty the elasticity of such responses. But the general principle, one of the few tested propositions we have, applies: the more expensive a careless action is made, the less of that action will be taken; and the less expensive the careless action is made, the more of the action one should expect. This theorem of the sloping demand curve is the basic tool that I will use in seeking the implications of products liability arrangements. The analysis cannot reveal what ought to be done in any ultimate sense, but it can indicate some relevant consequences of moving from or toward producer liability without fault.

Most people would regard these consequences as being relevant simply because intuition suggests that behavioral changes resulting from a policy are likely to be pertinent. In a technical sense the reason is probably as follows: while few persons regard economic efficiency in the sense described above as their overriding objective or criterion, most of us have enough to gain from this kind of efficiency to keep it in mind as one of our important objectives. Congressional debates and hearings suggest that congressmen do give some weight to economic efficiency, to market prices and, therefore, to voluntary exchange and Pareto optimality (though they would not use such a terml). They do not have in mind the precise technical meaning of efficiency, yet the imprecise concepts they do have in mind certainly appear to be related to the technical concept. The weight placed on efficiency by congressmen strongly suggests that most voters-most persons in the society-attach some value to economic efficiency. They are willing to trade some efficiency for other objectives (for instance, fairness) when it is too expensive to bargain for efficiency plus the other objectives, but they are not willing to forget about economic efficiency entirely. For these reasons, the policy consequences that economics can trace out are relevant not merely because they are among the consequences but because they are consequences that most persons feel are important.

\section{B. More Specific Issues: Consequences of Making Various Groups Liable}

With the preceding discussion as background, we can ask in a more systematic fashion: what are some of the important consequences of 
having liability assigned in various ways? We shall examine a spectrum of possibilities from customer liability without fault to producer or taxpayer liability without fault.

To begin, what would be the consequences of complete caveat emptor-of having customers watch out for themselves and pay the losses that occur in using a product? ${ }^{107}$ This arrangement would lead to economic efficiency - to the production of safety features, caution in using products, etc., by those parties having a comparative advantage in producing each item-if there were zero negotiation and enforcement costs. ${ }^{108}$ Purchasers of products would hire producers to reduce product hazards and "bribe themselves" to exercise care as long as these actions paid. What about injured third parties? If buyers of items were liable, they would modify their product selection and hire third parties to be careful as long as the gains outweighed the sacrifices. Thus, bargaining would lead to efficiency in producing safety features, warnings and instructions to users, warnings to bystanders, care in using products, caution in standing or walking nearby, and so on. (Or, another possible arrangement would be to make bystanders liable for injuries to themselves. Again, if there were zero transaction costs, voluntary exchange would lead to the same result as above, since the third parties could costlessly get together and hire manufacturers to make safer products or users to handle them more carefully. Whoever could prevent accidents at the lowest cost would again be hired to produce the accident prevention.) ${ }^{109}$

Because of the stochastic or chance element in accidents, insurance policies (as well as instructions and warnings) have value. Insurance affects resource allocation, not merely because it is a product that becomes valuable under uncertainty, but also because, with the existence of transaction costs, insurance affects behavior. Individuals will take out more insurance as long as the extra gain exceeds the extra cost. Due to information and other transaction costs, the premiums and changes in the premiums cannot accurately reflect marginal risks; the

107 Perhaps the phrase never really meant complete customer liability. Hamilton says that the first appearance of the phrase was apparently in the 16th century, and even then there was a condition attached: “... if he [a horse offered for sale] be tame and have ben rydden upon, then caveat emptor." FrTZHERBERT, BOKE of HUSBANDRIE § 118 (1534), quoted in Hamilton, The Ancient Maxim Caveat Emptor, 40 YALE L.J. 1133, 1164 (1981).

108 Zero transaction costs also implies zero costs of information about products' characteristics, though not a world of complete certainty in this analysis, for such a world would have no accidents, unforeseen events, or doubts about liability.

100 Even in these hypothetical situations yielding efficiency, many would object to the fairness of making the customers rather than some other set of persons bear whatever cost is incurred (though the cost of accidents would be partly shifted, much as most tax burdens are partly passed on to other groups). 
careful and the lucky will to some extent subsidize the careless and the unlucky. If there were certainty, of course, no one would insure the ones who were going to have accidents, and no one who was not going to have accidents would pay for insurance. Since premiums will "have more nearly lump-sum than marginal tax effects,"110 and will not be fully sensitive to individual behavior, the insurance holders will tend to use less care as long as this pays, and to buy less safe equipment as long as the extra gain exceeds the extra cost. While individuals in general are reaching preferred situations, since they value insurance more than the costs, one would expect total accident costs to go up. Moreover, this might subject bystanders and those who do not choose to carry insurance to somewhat greater dangers. ${ }^{111}$

Transaction costs are important to one's views on products liability mainly, however, because they affect the bargaining process in connections other than insurance. Contracting for more safety features or more cautious use of products with a million individuals separately, forming groups to negotiate smaller numbers of contracts, deciding in specific instances precisely what each contract means, enforcing agreements when people have enough assets to honor their bargains, enforcing contracts when parties go bankrupt-all these activities are expensive (in some circumstances extremely expensive).

With customer (or product owner) liability, however, note that certain transaction costs are in fact relatively low. The costs to users of hiring producers to make safer products and issue warnings and instructions would be comparatively low, for the established market relationships would permit customers to register their preferences and exchange money for safer products, instruction, and so on. To many people who have become acutely aware of the hazards of using modern products, or to those convinced that private enterprise is malevolent, the preceding statement may seem laughable, for if one visualizes himself as being injured, financially or physically, by defective merchandise, it does seem that he is at the mercy of producers. It is frustrating to have a persistent oil leak in a new car, to find that your dry cleaner has lost a pair of your trousers (though he insists that you must have lost them), to find that a hairspray has caused your wife to have an outbreak of eczema. Nonetheless, as these disappointments occur to thousands of customers, they turn to other products or producers-unless upon reflection they prefer the "lower price plus that risk" to "higher prices with reduced risks." Producers find it profitable to make

110 Williamson, Olson \& Ralston, Externalities, Insurance, and Disability Analysis, 34 ECONOMICs 235, 244 (1967).

111 One can observe some of the effects of insurance, in the presence of information and enforcement costs, in the rising costs of various forms of health insurance. 
a larger proportion of their products safer, issue instructions and warnings, carry insurance, and have better warranties or more generous returned-goods policies. Hence, while disappointments and injuries never cease in a changing and uncertain world, customers are able in the aggregate to influence product design simply by turning to competitors and bidding more for the goods that they prefer.

Transaction costs become greater if customers deal with firms that are protected from the entry of competitors. They have to appeal to customers, but they may not cater to customers' preferences as fully as they would if threatened by rivals. Transaction costs are still higher if one buys from a government agency and tries to hire this producer to offer a safer, or cheaper but less safe, or otherwise modified product. If the post office loses your books, or the public school damages your child, or a regulatory agency refuses to allow you to buy synthetic milk that looks like cow's milk, or a publicly owned highway or reservoir strikes you as being dangerous, the threat of your turning to competitors will not affect the design of the output. Hiring these producers or regulators to alter product design takes the more expensive form of organizing pressure groups to register voter preferences.

Buyer liability would hold another transaction cost in check: the cost of information about what degree of product safety for particular uses is economical, that is, does not result in an excess of costs over gains as seen by each individual for himself. The buyer-user is in a better position than anyone else to know the exact use he plans to make of a product and what alternative qualities, or degrees of safety, would do to his costs and gains. The manufacturer knows more about the product, but the customer, if he is liable, has a special incentive to obtain and make appropriate use of this information. To get the information, the buyer must deal, not with thousands of individuals, but with the seller and a few other identifiable persons. The result will not be the acquisition of complete information; it will not be the existence of perfect foresight or the absence of all mistakes and injuries. Whatever the product liability rule, the world will still be full of accident, tragedy, and disappointment. The only assertion here is that customer liability would often reduce part of the information costs, enabling voluntary exchange to go a bit further.

For some product categories such as new and complex items, however, customer liability might well lead to higher information costs than, say, producer liability. In the process of exchange, customers probe to find out how much information it is profitable to buy, and producers probe to determine how much it is profitable to produce.112

112 Perhaps it should be noted that I am not considering fraud or deliberate misrepresentation. These phenomena, like theft or contract violations, are undeniably expensive, 
With caveat emptor, the generation of the efficient amount of information may take quite a while, with either excessively cautious or insufficiently cautious use of the product occurring during the interim. For product categories like new drugs, ${ }^{113}$ the process might well be comparatively expensive. One cannot legislate these information costs out of existence, but it is always possible that intervention or different incentives would yield more gains than costs (vice versa is also eminently possible). Putting liability on the physician, ${ }^{114}$ for example, might induce him to acquire more information, reveal more information, and use new drugs more cautiously. The result would be partly cost and partly gain, but the magnitudes would be very difficult to ascertain. As Demsetz has pointed out, in deciding what government intervention is efficient, "[t] he primary problem [since the effects or "outputs" are not marketed] . . is the estimation problem."115

Customer liability would also keep another transaction cost comparatively low-that of bribing the users to be careful in employing the product. For the user would most frequently be the customer or an acquaintance or a member of his family. Thus, if he is liable for losses, he has to get the cooperation, not of thousands of strangers, but of himself and a few individuals with whom he has frequent personal contact, in insuring the exercise of an appropriate degree of care. This does

raising information and other transaction costs and reducing the scope for voluntary exchange; and they warrant considerable (though not an infinite) expenditure of resources to deter them.

113 To see the difficulty vividly, pick up an issue of the Journal of the American Medical Association and look at the advertisement for an anti-depressant, say Tofranil. You will find warnings about possibilities of conduction defects, arrhythmias, and tachycardia; warnings against use by patients receiving guanethidine; and mention of dozens of side effects. Most persons will recognize some of these side effects, such as drowsiness, impotence, or decreased libido; but how many will know what alopecia, eosinophilia, and agranulocytosis are? (The package circular indicates dozens of other possible adverse reactions, and there are additional side effects that are not yet listed.) Needless to say, the patient knows little about which effects are important and probable. The information has to be interpreted by a physician, and, quite understandably, he rarely mentions these effects or gives the frightening circular to the patient. He simply judges (inevitably on the basis of fragmentary information about the patient and the drug) whether the drug seems likely to do more good than harm, and tells the patient to keep in touch as this is strong medicine. The patient must fall back on getting information about alternative doctors and on choosing his doctor wisely. The point here is (a) it is costly for each of the parties involved to get information, (b) the value of the information that might be acquired is of uncertain value, for information acquisition (like research and development) is a search for something whose features are initially unknown, and (c) it may take a long time for caveat emptor to lead to an equilibrium. It is certainly possible that a different liability assignment would reduce total costs.

114 See Averbach, Physician's Liability for Prescription Drugs, 43 ST. JoHN's L. REv. 535 (1969).

115 Demsetz, Some Aspects of Property Rights, 9 J. LAw \& EcoN. 61, 68 (1966). 
not mean that he will be as cautious as it is humanly possible to be; it merely means that he will choose by weighing the costs of extra care, such as loss of time, against the benefits, such as the reduced risk of suffering uncompensated losses.

With user liability it is expensive-as it would also be with either victim or producer liability-for potential bystander victims to get together and bid for safer products, better instructions, more warnings, greater care by the user, and so on. In fact, I can visualize no arrangement that would greatly reduce transaction costs for third parties in bargaining for what they prefer. One could make taxpayers liable for all bystander claims-and one might prefer this from the viewpoint of fairness-but the arrangement would not facilitate discovery of what price various third parties would pay to have safer products.

Customer liability without fault would not impose as strong a deterrent to dangerous products as would liability according to fault, for any deterrent effect would depend solely on the threat of customers switching to rival products. If liability were placed on the party at fault, this would introduce an additional deterrent, the threat of liability if producers turned out clearly defective products that resulted in injuries. Would customer liability without fault therefore yield inefficiency? It is difficult to say, for the answer hinges on whether the shifting of patronage or that plus the instigation of lawsuits against producers would yield lower total costs, including the costs of identifying defects, of having accidents, and of adjudicating disputes. The shifting of patronage takes time and also entails the cost of numerous disappointments or accidents. A lawsuit over a defective product may deter the production of it before many users have been injured, though on the other hand court costs for maintaining this system are not negligible. As a result, most persons would probably judge that customer liability without fault would be inefficient in connection with many products (for example, those that might cause serious or repeated accidents) but efficient in connection with other products.

On balance, one can say only that customer liability without fault has some consequences that many persons would regard as desirable, but it will not by any means yield a tidy economy free of misery and possible inefficiency. One may legitimately believe it is possible to do better: perhaps because he has some criterion other than the one (Pareto optimality) in terms of which we have been discussing costs and gains; perhaps because information and transaction costs leave room for doubt about one's success in working toward that criterion. In short, while customer liability brings some advantages, there are several major reasons that might make one oppose customer liability: 
(1) One might believe that he could negotiate through the political process for liability assignments that would yield more equitable $e^{116}$ results but that high transaction costs preclude arranging taxes and subsidies that would yield an equally desirable wealth distribution and economic efficiency. This is in my view a powerful-and understandable-element in the thinking of opponents of caveat emptor. They believe they have a chance of securing a fairer outcome but no chance of obtaining the fairer outcome plus efficiency. (2) One might attach value to certain political procedures or arrangements per se and simply not care much about economic efficiency or Pareto optimality. (3) One might wish to protect other persons from taking the risks they would voluntarily choose to take, because he believes they do not know what is good for them. (4) One might believe that customer liability leads to less economic efficiency than other arrangements, since the issue is in doubt once negotiation and enforcement costs are recognized. It is in doubt because we could not quantify negotiation and other transaction costs if we introduced some other assignment of rights, and we do not know exactly what the costs or sacrifices would be if we introduced an element of compulsion (for example, compelling all buyers to take a safer product), since there would be no market observations to reveal what people would pay to have other choices. Since the matter is in doubt where transaction costs leave us with externalities, one must make personal judgments in deciding what arrangement he believes would yield economic efficiency. One person or a majority may judge that total costs could be reduced by departing from customer liability.

What would be the probable consequences of making sellers instead of users liable, but with fault and privity required-as has been the case over many decades of our history? Roughly speaking, one could say that in these circumstances the person judged to be at fault, or the unlucky victim where no fault existed or at least no fault could economically be determined, would bear the initial burden. Thus, users or retailers not at fault might often bear the cost because fault could not be established or because the court costs of trying to determine liability would often be higher than the expectation of reimbursement. Thus, sometimes the sellers and sometimes the buyers or users would be liable. Users would have a greater incentive than they would have under producer liability without fault to use products carefully and to bargain for safer products. Also, lack of assets or bankruptcy would sometimes shift the burden, and the possibility of these events would affect resource allocation, again presumably inducing users, merchants,

116 That is, distributional impacts that one prefers. 
and third parties to be more careful and inducing users to bid more for safer products, than would be the case with strict liability of producers.

This arrangement induces most persons and producers to carry liability insurance, and induces many product owners to carry accident insurance, but insurance companies cannot ordinarily survive if they pay off regardless of fault, and the system involves heavy court costs whenever insurance companies or others deem it worthwhile to initiate lawsuits. One of the costs that goes up with a fault system, then, is the set of information, decision-making, court, and other transaction costs associated with efforts to determine misuse, negligence, defects, and other factors that may suggest fault. These costs are one of the reasons that some have urged the adoption of new insurance schemes in connection with automobile accidents. While most automobile accidents are not products liability cases, their handling does involve some of the same issues, and new liability schemes for such accidents will therefore be discussed later in this paper.

A consequence of privity that has been much discussed is that, if fault lies with the manufacturer, seemingly unnecessary costs are involved if the final purchaser must sue the retailer, the retailer must sue the wholesaler, and the wholesaler must sue the manufacturer. A few cost-reducing devices have been introduced, but unquestionably this is a large expense implied by a privity-fault system of liability assignment. On the other hand, if the manufacturer can be sued directly, one might end up with the wholesaler and retailer being less careful and, if there was doubt about who was to blame, with the manufacturer suing the wholesaler and the wholesaler suing the retailer. (The extreme case of making the manufacturer liable without fault will be discussed later.) Still, it does seem that in some instances some of the lawsuits entailed by the privity requirement could be avoided.

The privity-fault system of liability assignment tends to increase another transaction cost in comparison with the purchaser-withoutfault system: the cost of hiring users to be careful in choosing and employing products. This cost goes up because, with the lowered probability that the purchaser will be liable, the cost to him of being less careful or of selecting a less safe product goes down; he will tend to take more of "less careful behavior" and "less safe products," and hiring him to behave otherwise becomes more difficult. Determining how many "units" of extra care one's payment was buying, and making sure that the user did in fact exercise that much extra care, would be prohibitively expensive. The magnitude of this impact might be small, 
for the net reduction in the penalty for carelessness might be small. After all, carelessness would in any event bring some cost-some probability of pain and inconvenience (or even death) and the residual probability of being liable. But the direction in which behavior would shift is surely clear.

Buyers will still have a relatively cheap way of registering their preferences and hiring producers to produce the safety features that buyers are willing to pay for. As before, their willingness to pay different amounts for different products would shape the profitability of different product lines and designs. Producers will now carry liability insurance, however, which may affect the other penalty for producing less safe products-the expected cost of being held liable. Insurance premiums cannot economically be adjusted neatly to reflect risks. If a less safe product is involved in only a few small lawsuits against the insurance company, it may have little or no impact on the insurance premium that a producer must pay. Beyond some threshold, though, a bad record may bring a sizable increase in a producer's insurance premium. As noted earlier, the effect may be more like a lump-sum tax than a marginal tax on unsafe products, watering down the tendency of a fault system to induce the producer, over certain ranges, to turn out safer products. Perhaps it should be mentioned again that these changes in liability assignment have such effects because transaction costs make it uneconomical for voluntary exchange to "get around" special constraints or institutional arrangements.

What are the consequences of moving further toward producer liability-of reducing the chances that the purchaser will be held liable and of increasing the chances that the producer will have to bear the burden? This, to repeat, is what seems to have happened. ${ }^{117}$ The consequences of further moves in that direction would be to intensify the impacts noted above. One might expect more court cases and court costs, greater difficulties in bribing purchasers to be careful, more efforts to publish warnings and instructions (perhaps disclaimers, if they still gave producers some shelter), a greater tendency to produce safer products, a smaller range of product choice for poor consumers, and a partially offsetting tendency to neglect safety because of the more extensive use of liability insurance.

Let us turn now to a rather extreme arrangement that has been mentioned in recent years-producer or manufacturer liability without fault or defect. As in the other cases, if there were zero transaction costs, producers could bribe customers to be careful, bystanders could pay users to be careful and producers to issue safer products, and 
customers could hire producers to provide desired safety features. Each would take these actions as long as the extra gain exceeded the extra cost, and resource allocation would end up at an efficient point. With transaction costs, however, producer liability without fault would alter resource allocation quite a bit. The manufacturer would simply be held liable for all injuries occurring with the use of his product, regardless of circumstances. The cost of hiring thousands of purchasers or third parties to exercise care would be huge, and therefore these persons would now find it comparatively inexpensive to be careless. Accident rates would rise, and producers, being liable, would find it economical to restrict their product lines to safer products and designs. The net impact on accident costs is not clear, but total costs would increase, because accident prevention would not be produced by those having a comparative advantage in doing so. Consumers would face a narrower range of choice, an important sacrifice, but one that is impossible to evaluate in any generally valid fashion. Poor people would be hardest hit by this particular cost, because their options would now be to buy relatively expensive, safe products or nothing at all. Insurance premiums would be prohibitively high except on extremely safe products, thus doing little to weaken the shift toward such product lines.

Disclaimers would serve no purpose and would disappear. Unlike the case of purchaser liability without fault, disputes and court or administrative costs would not be nil, because even if fault did not have to be established, the fact and extent of injury presumably would have to be established. (Otherwise, claims would be infinitely large.) The higher accident prevention costs would be paid largely by the customers in each industry in the form of higher prices. Consumers in some industries that already produced extremely safe products (for instance, paper clips, books) might be affected, for as people shifted their purchases away from the higher prices in Industry $A$, it might drive up prices in Industry B. Also, producer rents would be reshuffled somewhat; owners of inputs that had been receiving rents in industries producing comparatively unsafe products would now find the demand for those inputs declining, and those owners would bear part of the burden while owners of certain other inputs would begin collecting economic rents. Whether or not one regarded these shifts in wealth distribution as being fair would depend upon the precise impacts and upon one's value judgments.

Such effects on wealth distribution lead to questions about other possible arrangements. Many persons believe it is more equitable to spread the burden of accident costs over all the customers of particular 
industries, ${ }^{118}$ for example, to spread the burden of aircraft accidents over customers of airlines or aircraft manufacturers or both. As far as equity is concerned, however, this redistribution still seems to be rather arbitrary. Why not shift the burden, or part of it, to another industry, or to a collection of corporations and their customers? But how can one feel confident that these persons would be those with "deep pockets"? How about shifting the costs to taxpayers in general, since we believe that we have a somewhat progressive tax structure?

One way of accomplishing this would be to have government compensate people for all losses without regard to fault. Of course a claim that an injury or loss had occurred would have to be checked, so there would still be this sort of administrative or court cost. Note, however, that neither customers nor manufacturers (nor bystanders) would now have to worry about bearing the burdens, so that carelessness in design and use of products would become relatively inexpensive. As the cost of selling unsafe products went down from producers' standpoints, they would take more of this action. As the cost of failing to inspect products or of using products carelessly went down from customers' standpoints, they would take more of these actions. If officials or taxpayers thought of hiring these persons to alter their behavior, ordinary bargaining would be prohibitively expensive. One way to induce them to behave differently would be to change the law and revert to the assignment of liability to purchasers and/or producers, but the transaction costs of getting laws changed are exceedingly high. Besides, our purpose at this point is to examine the implications of taxpayer liability.

It is almost certain that voters and their representatives would be displeased with this situation. Costs would rise too much. Liability insurance-in this extreme arrangement-would serve no one's purpose and would disappear. Without governmental regulation, warnings and instructions would decline in importance in comparison with a producer liability system. To make taxpayer liability workable, government would have to devise a vast network of specifications for products, rules for their use, and required instructions and warnings. Some of the "unavoidably unsafe products" might be banned altogether. Producers would inevitably face penalties (a kind of liability) for violating the specifications and requirements. Again, consumers would find their choice narrowed, as they would be unable to buy cheaper, although relatively unsafe, products if they preferred them. Penalties for negligence in using products would be devised in order to enforce

118 Some of the burden would be borne by owners of specialized inputs, such as laborers with specialized skills. 
regulations concerning the use of products. Enforcement costs would be high. In the end costs would be shared by taxpayers, customers and potential customers, and to some extent by certain owners of inputs that had formerly collected rents (though owners of certain other inputs would now be better off).

Liability for automobile accidents is a quantitatively important example of liability assignment that has received considerable publicity in recent years. Most automobile mishaps involve either driver negligence or plain bad luck rather than defective products, yet the accidents result from using a product. If one considers eliminating the fault principle, it is hard to distinguish these cases from the products liability category. In any event, these accidents raise many products liability issues, and I believe it is worthwhile to examine them.

For many years there has been much dissatisfaction with the current liability arrangements. ${ }^{110}$ Since many variables contribute to the genesis of accidents-weather, visibility, drivers of the cars involved, drivers of other vehicles, pedestrians, dogs, the precise condition of brakes and other equipment even if not "defective," and road conditions-it is very difficult to assign responsibility. Court and administrative costs are high, and the outcomes are often inequitable in the eyes of many persons. ${ }^{120}$ Many specific features of the present system are of interest-court congestion (it often takes several years for a suit to come to trial), the lack of any way to collect partial reimbursement in advance unless the case is settled out of court, the tactics used, the unreliability of witnesses' observations and memories (quite apart from perjury), the chances of winning in court (if the injured victims were at fault in any way, they cannot collect), the chances of collecting once one wins (insolvent defendants), the economics of out-of-court settlements. But all of these things lead to two general observations: the system is costly and often unfair. Naturally, the question arises: Can a better system, or one that most persons would prefer, be devised?

Although a number of variants have been considered, the one that has probably attracted most attention is the Keeton-O'Connell Basic Protection Plan. Under this Plan motorists would be compelled to carry insurance, with competing private companies, and victims would be compensated without regard to fault. The amounts to be paid would not be according to a fixed schedule for various injuries, as it

110 See, e.g., A. Ehrenzweig, "Full Aid" Insurance for the Traffic Victim: A Voluntary Compensation Plan (1954).

120 For excellent discussions and more details, see Green, supra note 106, at 67-80; or R. Keeton \& J. O'Connell, Afrter Cars Crash: The Nefd for Legal and Insurance Reform (1967). The original Keeton-O'Connell study was Basic Protection for the Traffic Vicrim (1965). It includes a lengthy bibliography on the subject. 
is under workmen's compensation, but would presumably be according to receipted bills from hospitals, doctors, etc., as is usually the case under major medical insurance. Thus, as far as motorists are concerned, it would be compulsory loss or accident insurance rather than liability insurance.

To achieve the economies that are being sought, there would be a ban on negligence suits for less than $\$ 10,000$ and on pain and suffering suits for less than $\$ 5,000.121$ These bans would presumably reduce court costs, since in many instances, suits could not plausibly be initiated for amounts as large as the above. However, if lawyers would accept the cases on a contingent fee basis, there would be an increase in the number of negligence suits for $\$ 10,000$ and pain and suffering suits for $\$ 5,000$.

I am not clear about what would happen to pedestrian victims, but their claims might be thrown into the category of "assigned claims"those that are assigned to individual insurance companies in some designated proportion. The claims of motorists who seem to be injury prone (high-risk drivers) might be handled as assigned claims also, though Keeton and O'Connell apparently would not raise their premiums. Nor would they raise the premiums of drivers who were involved in numerous accidents even if they themselves suffered few injuries. The authors suggest that it appears to be politically impossible to charge bad drivers the full cost of the risks they generate or to "rule bad drivers off the road." At the same time they seem to feel that high rates to bad drivers have little deterrent effect over and above the deterrent effect of legal penalties.

What would one expect to happen ${ }^{122}$ To repeat an old refrain, if there were zero transaction costs, voluntary exchanges could lead the economy to an "efficient" (Pareto-optimal) allocation of resources under this liability assignment too; for drivers, manufacturers, insurance companies, and third parties could hire each other to act so that the Pareto optimal amount of accident prevention would be undertaken and the actions would be taken by those having a comparative advantage in doing so. In the real world about all we can say is that certain costs would be increased, others decreased, and wealth distribution altered slightly under the Keeton-O'Connell Plan.

121 As at present, one could not recover for pain and suffering in any event unless he could show negligence.

122 For a thorough discussion of such automobile plans, see BLUM \& KALvEN, supra note 104. See also Calabresi, Fault, Accidents and the Wonderful World of Blum and Kalven, 75 YALE L.J. 216 (1965), and Blum \& Kalven, The Empty Cabinet of Dr. Calabresi: Auto Accidents and General Deterrence, 34 U. CHI. L. REv. 239 (1967). 
It is almost certain that court and legal costs would be reduced, because fault determination would be irrelevant in most accidents. Since the cost to motorists of small accidents would decline (they would not be liable personally, and their insurance premiums would not be sensitive to their accident records), such accidents would increase, but small accidents would not lead to court cases. In major accidents, there would still be suits for negligence and pain and suffering reimbursement. Even these accidents would presumably occur a bit more frequently, but the cost to drivers of risking major accidents would be reduced only a little; and people might exercise almost the same degree of care at high speeds or in particularly dangerous conditions. The number of $\$ 10,000$ suits for negligence and $\$ 5,000$ suits for pain and suffering would increase, but these extra costs could hardly offset the reductions in other legal costs.

Automobile compensation plans would increase other costs, however. One basic reason is that accidents (small ones especially) would now be less expensive to drivers-that is, they would bring smaller penalties-and motorists would be somewhat less concerned about safety features in their cars, preventive maintenance, and careful driving. Accident rates could be expected to rise. Many people doubt this, but in all the instances observed so far, people take more of any action or commodity that is made less expensive (provided the attributes of the item remain the same). To repeat an earlier point, people who doubt that liability deters accidents usually feel: Who would be willing to risk death just because the action would cost him a few dollars less? But we risk death (increase slightly the chance of being killed) every day to get a newspaper or a pack of cigarettes. People get into hazardous occupations to earn a few extra dollars per month. Only heroes or suicides take actions that involve extremely high probabilities of death or serious injury, but all of us trade modest increases in those probabilities for modest savings or rewards.

If accident rates increased, then accident costs would rise. Administrative costs would rise, not only because accidents were more numerous but also because small claims that would have been dropped under the fault system would be filed under a compensation without fault system. ${ }^{123}$ Since it would presumably be easier to collect on fraudulent claims, unless extra policing costs were incurred, there might be more claims of that variety. Moreover, claims would be larger than under a fault system. Just as people with broad coverage health insurance enter hospitals more frequently, stay longer, take better rooms and

123 Blum and Kalven refer to this as increased "claims-consciousness." BLUM \& Kalven, supra note 104 , at $51-52$. 
more service-automobile victims would accept more x-rays, better treatment, longer hospitalization, and so on.

One cannot define with much confidence the magnitude of these impacts. But to me it seems likely that the government would have to regulate behavior and introduce other penalties if compensation without fault were introduced. Under workmen's compensation, costs have been high, fixed schedules of awards are used, victims are apparently not fully compensated after all, and the experience has not been entirely encouraging. ${ }^{124}$ It seems likely that government would have to extend and stiffen penalties for negligence in driving, set up a fixed schedule of awards or pay only a percentage of each total claim, or let insurance premiums get out of hand, penalizing poor persons who need to drive. It is not clear that the final incidence of the burdens would be particularly equitable.

If we examined a social insurance plan, similar comments could be made. The consequences would be similar in nature, though I conjecture that they would be more drastic in degree if accident costs were initially placed on the taxpayer. One may legitimately prefer a compensation without fault or social insurance plan, but analysis suggests once again that a free lunch is not to be expected: When considering a change that would bring gains, one cannot neglect the costs or disadvantages against which the gains must be weighed.

\section{Critique of Arguments in the Literature}

Are the implications of different assignments of liability being discussed critically? The answer, it seems to me, is generally "No." We are not yet discussing these implications with much precision and care. There are certainly exceptions, and the literature contains much that is perceptive. For my purposes here, however, I shall focus attention mainly on statements and arguments that may suggest a certain amount of "negligence" in manufacturing our product of articles and views about products liability.

One striking feature of the literature is the emphasis by many writers on equity or fairness almost to the exclusion of any other considerations. Perhaps this view of the literature is incorrect, but that is the way it often comes through to this writer. If this is so, then we are thinking uncritically in the same sense that the six blind men were being uncritical in the old poem about feeling an elephant. (One man decided the elephant was like a rope, another concluded it was like

124 Id. at 25; Riesenfeld, Basic Problems in the Administration of Workmen's Compensation, 36 MINN. L. REv. 119 (1952). 
a wall, and so on.) I do not mean to say that fairness is unimportant; on the contrary, it is clearly one of the most important considerations. But one should at least ask himself whether or not there are other relevant considerations in designing products liability policy.

At the extreme, most people recognize an interdependence between their notion of equity in distributing wealth and the amount of wealth to be distributed. They see too that it may be sensible to sacrifice some of one objective to achieve some of another. For example, most persons who regard it as equitable to guarantee that everyone is equally wealthy, regardless of their behavior, realize that this might affect the total amount produced and made available. In less extreme examples of wealth redistribution, however, we often neglect even to inquire about the consequences. Protecting and compensating consumers (or producers, or third parties) are instances of wealth redistribution that may have effects on total costs and net output in addition to their impacts on fairness.

One may believe that these impacts on total costs and net output would be trivial. In that case, the clear way to discuss the matter would be to say: "I believe, though I cannot prove, that the effects other than those on wealth distribution would be insignificant." And some authorities have in effect done this-which is a more critical way of examining policies than simply to ignore part of the considerations.

The emphasis on equity was illustrated earlier in this paper. ${ }^{125}$ Other examples include such statements as: "Should a manufacturer, in a free bargain, be able to limit or exclude his obligation? The answer to this question is primarily one of loss allocation ...."126 Or consider the following:

If in time the accident problem is solved through some compensation scheme that covers the basic economic losses of accident victims, it will remain to be seen whether the law of negligence as we know it today in this area will atrophy or will survive in a diminished role to afford additional compensation to victims whose injuries are caused by actual fault on the part of others. Money damages, of course, can never really compensate for the noneconomic losses resulting from personal injuries. Although it is therefore reasonable to exclude such losses from coverage in any purely compensatory system, inherent justice between the person injured and the person who caused the injury may demand compensation for such losses when the latter was actually at fault. Some- 
thing of this sort has apparently taken place in England. The adoption of broad social insurance to cover accident and other losses has been followed by judicial limitation of strict liability in tort. Liability for negligence remains, however, and the problem of double recovery is resolved pragmatically by deducting one-half of the social insurance benefits that would be received for the first five years after the accident from the damages for lost earnings. ${ }^{127}$

The passage seems to suggest that the accident problem is solely one of finding a just compensation scheme. Prosser mentions that the law of torts is "concerned with the allocation of losses arising out of human activities," 128 and (although court decisions frequently do take other factors into account) there is usually little in discussions of tort law to indicate that anything else might be relevant to one's preference regarding the law. Many other authorities appear to be concerned almost solely with the question of who deserves sympathy-the manufacturers or the consumers. ${ }^{129}$ One writes that " $[\mathrm{t}]$ he trend toward greater consumer protection is simply a manifestation, appropriate to a mass-producing, mass-marketing, and mass-advertising culture, of a purpose to lighten the burden of the plaintiff injured by defective products or, I should add, by dangerously inadequate service."130

Moreover, whether or not the emphasis on equity reflects a neglect of other considerations, the discussions of equity themselves often appear to be somewhat uncritical. ${ }^{131}$ While most of us would agree that our ideas of fairness frequently call for compensating purchasers or third parties, the issues are not simple if the compensation rules would result in a reduced range of choice open to consumers. For it is the poor in particular who would suffer if they could never elect to buy a low quality item-never elect to shoulder extra risk in exchange for a lower price. Reducing the options open to a poor person is a further reduction in his well-being as he sees it.

127 Traynor, supra note 75, at 376. In connection with this passage Traynor cites W. Friedman, LAw in A Changing Societr 155, 158 (1959), and James, Social Insurance and Tort Liability: The Problem of Alternative Remedies, 27 N.Y.U.L. REv. 537 (1952). 128 W. PROSSER, HANDBOOK OF THE LAW OF TORTS 6 (3d ed. 1964). See also his section on "social engineering" beginning at 14, particularly the passages on the "capacity to bear the loss" at 22.

129 See, e.g., Note, The Uniform Commercial Code and Greater Consumer Protection under Warranty Law, supra note 34, at 268; Green, supra note 4, at 930.

130 Cowan, supra note 53, at 1092.

131 One writer, after mentioning some of the relevant economics literature, somehow concludes, "Thus economic reasons support a defence of strict liability in terms of fairness-an equitable distribution of losses." Kessler, Products Liability, 76 YALE L.J. 887, 925 (1967). 
Also, the issues are not simple if the compensation rules would transfer wealth in a complex, partly capricious fashion-for example, from one mixture of poor and rich consumers (or of rich and poor taxpayers) to some other unspecified mixture of rich and poor persons. And, in fact, the identity of those who would bear the burden under different rules is not obvious. The problem is similar to that of the incidence of excise or business taxes, where one can say something about what groups will bear the burden but not much about the proportions in which they will bear it or the circumstances of the individuals involved.

Blum and Kalven have discussed some of these issues thoughtfully, raising the question, for instance, whether it is equitable to help particular groups of injured persons while doing nothing special for others such as cancer victims. ${ }^{132}$ Prosser has pointed out that the manufacturers are sometimes small struggling concerns compared to the retailers, who may be nationwide distributors or chain stores ${ }^{133}$ (the implications in terms of the fairness of products liability rules simply being unclear).

Thus, even if we all agreed that people below a certain wealth level should be helped, or that unlucky victims regardless of wealth should be helped, the unevenness of and uncertainties about the incidence of the burdens would still make the issues complex. In the final analysis, moreover, people are not agreed on criteria of fairness; so for this reason, too, sweeping statements about what equity dictates are hardly warranted. We must debate these important issues, but it would presumably be more helpful if we could do so with increased caution and accuracy.

Many writers have given some attention to considerations other than equity, such as the economic effects of alternative products liability arrangements. Some of the discussions have been extremely perceptive, but a good deal of the time the generalizations are too broad or the inferences that are drawn are not warranted. Often there seems to be a conviction that consumers have no influence on producers (or could not conceivably prefer low quality outputs at low prices) or that producers are completely free to behave as they wish. "To put the matter bluntly, a large proportion of mass products are consciously made as inferior as the traffic will bear and are advertised by conscious misrepresentation as far superior to their known quality. The combination of low quality production and high quality lying makes it impossible for those using the products of mass manufacture to distinguish

132 BluM \& KalveN, supra note 104, at 42-44.

133 Prosser, supra note 36 , at 816 . 
good merchandise from bad without the services of a general testing laboratory." 134 Or "... . what of those products which are clearly unmerchantable -in a phrase, third-rate merchandise ... . ?"135 Or, according to one opinion, "I would describe the tort simply in terms of a policy prohibiting the imposition of an unfair 'bargain' upon members of the public who are forced to buy a needed product."136 I am frequently angered by products that break, or by my failure to get more information about products prior to purchase, or by advertisements that annoy me. Yet it is not correct that producers can do whatever they wish and survive, or that I have no option of buying better products, or that $I$ am unable to get more information about products, or that advertising really misleads me much. Life is difficult; all one can do is grope for better rather than worse arrangements.

Another tendency in discussing economic effects is to make strong assertions where there is little evidence or even where there are tested hypotheses that (until refuted) cut in the opposite direction. The following statement may illustrate this point: "Those who attack strict liability seem to feel that they have dealt it its most stunning blow by their reference to the effect upon the research on new drugs. A close examination of this assertion proves it to be without substance, however, since a company is impelled to search for and develop new drugs for its very existence .... No company will go out of business because of increased tort liability." ${ }^{137}$ This passage contains at least two questionable conclusions, perhaps due to putting things on an all or nothing basis. (1) No company will fail just because its costs have been increased. A possibility that seems to have been discarded without much evidence is that some would survive but some on the margin would fail. (2) If companies do not fail, their behavior (for example, the amount and nature of their research) will be completely unaffected. Observations in other cases where an activity becomes more expensive suggest that whatever companies survived would engage in somewhat less, or less adventurous, research, though the quantitative significance of the shift would be uncertain. On balance, the argument is a bit like asserting, "A tax on milk will have no effects because dairy farmers are impelled to produce milk for their very existence, and no dairy farmer is going out of business because of increased taxes."

134 Cowan, supra note 53, at 1087.

185 Comment, supra note 58, at 1713 .

138 Price v. Gatlin, 241 Ore. 315, 325-26, 405 P.2d 502, 507 (1965) (O'Connell, J., dissenting).

137 Rheingold, supra note 69, at 1017. 
One frequently encounters statements that recognize the cost of proceeding in one direction but neglect the cost of going in the other direction. For example, ". . . due care should be encouraged by the law. Carelessness can only lead to waste of both lives and dollars."138 Here it is recognized that carelessness in producing products (and presumably in using them) entails sacrifice. Proceeding in the opposite direction, that is, exercising greater care, will not be free of charge, however, for more quality control and caution also entail costs. Suffcient care-enough to reduce the output of medicines or foods or to slow ambulances or fire engines drastically or to delay delivery of various products-would even sacrifice lives. Hence, as usual, in our efforts to choose better policies we have to walk the tightrope, weighing the costs of moving in one direction against the costs of moving in the other direction.

Another illustration of this point is provided by Prosser. "The public interest in human safety requires the maximum possible protection for the user of the product ...."139 If taken literally, "maximum possible protection" would reduce certain costs but would entail other far greater ones, for all appliances, vehicles, and antibiotics would either be banned or made as foolproof as is technically possible, which would make them too costly for most of us to use. The public interest, as defined by almost anyone, would hardly call for this result. If not taken literally, the phrase gives no guidance, but presumably says merely that the public interest requires the "appropriate" degree of protection for the user of the product.

When people ponder the provisions of more information to consumers, they often slip into the same sort of thinking. Consider some remarks of a Special Assistant to the President for Consumer Affairs:

The activities of the federal government in the 1960's with respect to consumers rest on four pillars-the four consumer rights articulated by Presidents Kennedy and Johnson. These are the right to be safe, the right to choose freely, the right to be heard, and the right to be informed. These rights are not merely clever phrases thought up by speech writers; they are indispensable if consumers are to be effective partners with producers and other organized interests in moving America forward. ...

This concept of full information is the principle under-

138 Franklin, When Worlds Collide: Liability Theories and Disclaimers in Defective Product Cases, 18 Sran. L. Rev. 974, 985 (1966).

139 Prosser, supra note 36, at 799. 
lying the truth-in-lending bill and the truth-in-packaging bill. The consumer's right to have full information is also the basis for the major recommendations flowing from the conferences held by the President's Committee on Consumer Interests. ...

Currently the concept of full information is not accepted in all segments of our society. There is only one way in which its acceptance will become widespread: the majority of the American public must recognize its validity and be able to express their opinion effectively. ${ }^{140}$

These statements are intended merely to illustrate a point, for it may be quite unfair to take these passages out of context and criticize their authors. (It is not economical for anyone to take the time to make all of his sentences rigorously correct.) These writers may have used such phrases as "maximum possible protection" or "full information" simply as shorthand ways of saying, "In my judgment it would be appropriate to provide more protection and information than are provided at present." Nonetheless, such quotations can serve our purposes here-to indicate that critical examination of the issues would lead one to complex and inconclusive arguments rather than to sweeping and dogmatic generalizations.

Also in conclusion I might re-emphasize that the products liability literature contains quite a few analyses which do recognize considerations other than equity (such as economic effects), the inherent diffculties of agreeing on what is equitable, the significance of permitting or of interfering with individual choice, the relevance of the law of demand and deterrence, and the possible impacts of products liability laws on total costs and output. ${ }^{141} \mathrm{~A}$ few writers have even drawn on the Coase theorem, recognizing that with zero transaction costs and voluntary exchange the assignment of liability would make no dif-

140 Peterson, Representing the Consumer Interest in the Federal Government, 64 MicH. L. REv. 1323, 1325-26 (1966).

Betty Furness, a more recent Special Assistant on Consumer Affairs, makes similar recommendations: "Why shouldn't the housewife know there are ' $x$ ' number of hours of service in her washing machine, or that the life expectancy of a toaster falls short of a golden wedding anniversary? The manufacturer knows, and the marketer knows. Shouldn't the consumer also know?" TrMe, Jan. 5, 1968, at 38. This makes it sound as though such information exists as a unique number rather than as some sort of probability distribution, as though consumers are more foolish than $I$ believe them to be, as though they cannot get more information at present if they are willing to pay higher prices, and as though it is obvious how much information it would be efficient to provide.

141 See, e.g., Franklin, supra note 138; Keeton, Is There a Place for Negligence in Modern Tort Law?, 53 VA. L. REv. 886 (1967); Plant, supra note 11. 
ference to resource allocation, but also recognizing that in the real world the implications of liability assignment are often complex and uncertain..$^{142}$

142 See, e.g., G. Calabresi, The Costs of Accidents: A Legal and Economic ANalysis (1970) and Calabresi, The Decision for Accidents: An Approach to Nonfault Allocation of Costs, 78 HARv. L. Rev. 713 (1965); BLUM \& KaLven, supra note 104. 